MÜHELYTANULMÁNYOK

DISCUSSION PAPERS

MT-DP - 2006/15

\title{
Central Bank Interventions, Communication and Interest Rate \\ Policy in Emerging European Economies
}

BALÁZS ÉGERT 


\section{Discussion papers \\ MT-DP - 2006/15}

Institute of Economics, Hungarian Academy of Sciences

KTI/IE Discussion Papers are circulated to promote discussion and provoke comments. Any references to discussion papers should clearly state that the paper is preliminary. Materials published in this series may be subject to further publication.

Central Bank Interventions, Communication and Interest Rate Policy in Emerging European Economies

\section{Balázs Égert,}

Oesterreichische Nationalbank;

EconomiX at the University of Paris X . Nanterre;

the William Davidson Institute at the University of Michigan

balazs.egert@oenb.at

and

begert@u-paris1o.fr

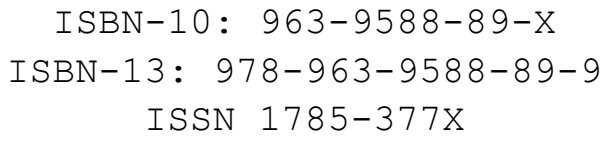

Publisher:

Institute of Economics, Hungarian Academy of Sciences 


\title{
Devizapiaci és szóbeli intervenció Európa feltörekvő gazdaságaiban
}

\author{
Balázs Égert
}

\section{Összefoglaló}

Ez a tanulmány a devizapiaci intervenciók eredmenyességét vizsgálja meg Horvátország, Csehország, Magyarország, Románia, Szlovákia és Törökország esetére az ú.n. "event study" módszer segítségével. Az eredmények azt mutatják, hogy az intervenciók csak rövidtávon és a hazai deviza felértékelődésére nehezedő nyomás enyhítése esetén sikeresek. Az intervenciókkal összehangolt jegybanki kommunikáció és kamatlépések azonban jelentősen megnövelik az intervenciók eredményességét. Az intervenciók árfolyamra gyakorolt tényleges hatása a horvát, cseh, magyar és kisebb mértékben a román jegybank által bejelentett hivatalos céllal egybeesik. Ez csak részben mondható el Szlovákia és Törökország esetében. Úgy találjuk, hogy Horvátország kivételével a jegybankok a devizapiaci intervenciókat többnyire sterilizálják. Ugyanakkor az is megfigyelhető, hogy az intervenciók nem kiemelkedően eredményesek Horvátországban. Ez azt mutatja, hogy a nem sterilizált intervenciók nem minden esetben hatnak az árfolyamra.

\section{Tárgyszavak:}

devizapiaci intervenció, jegybanki kommunikáció, event study, feltörekvő piacok. 


\title{
Central Bank Interventions, Communication and Interest Rate Policy in Emerging European Economies ${ }^{\dagger}$
}

\author{
Balázs Égert ${ }^{\ddagger}$
}

\begin{abstract}
This paper analyses the effectiveness of foreign exchange interventions in Croatia, the Czech Republic, Hungary, Romania, Slovakia and Turkey using the event study approach. Interventions are found to be effective only in the short run when they ease appreciation pressures. Central bank communication and interest rate steps considerably enhance their effectiveness. The observed effect of interventions on the exchange rate corresponds to the declared objectives of the central banks of Croatia, the Czech Republic, Hungary and perhaps also Romania, whereas this is only partially true for Slovakia and Turkey. Finally, interventions are mostly sterilized in all countries except Croatia. Interventions are not much more effective in Croatia than in the other countries studied. This suggests that unsterilized interventions do not automatically influence the exchange rate.
\end{abstract}

JEL: F31

Keywords: central bank intervention, communication, foreign exchange intervention, verbal intervention

$\dagger \quad$ I would like to thank Harald Grech and Zoltán Walko for useful discussion and two anonymous referees for very helpful comments and suggestions. I also thank the Croatian National Bank and the Czech National Bank for providing the data on FX interventions. I am very grateful to Irene Popenberger for excellent language advice. Part of the paper was written when the author visited CESifo in 2006. The opinions expressed in the paper are those of the author and do not necessarily represent the views of the Oesterreichische Nationalbank or the European System of Central Banks (ESCB).

$\ddagger$ Oesterreichische Nationalbank; EconomiX at the University of Paris X - Nanterre; and the William Davidson Institute at the University of Michigan. E-mail: balazs.egert@oenb.at and begert@u-paris10.fr. 


\section{Introduction}

The empirical literature on the effectiveness of - mostly sterilized - foreign exchange (FX) interventions in developed market economies remains fairly mixed despite the recent emergence of some more supportive evidence. ${ }^{1}$ In this context, Canales-Kirjenko (2003) argues that foreign exchange interventions may be more effective in emerging market economies than in well-established industrialized countries, because (1) central bank interventions are not always fully sterilized, (2) the size of interventions is large relative to market turnover in narrow foreign exchange markets, (3) the market organization and the regulatory framework may be more conducive to interventions or (4) moral suasion may play a bigger role.

Nonetheless, there is little empirical evidence with regard to the proposition that central bank interventions might be more effective in emerging market economies. This is also true for emerging European market economies, even though the number of country-specific studies has been on the rise recently. ${ }^{2}$ Against this backdrop, we add to the literature by scrutinizing the impact of daily FX interventions on the exchange rate in a large number of emerging European countries - Croatia, the Czech Republic, Hungary, Romania, Slovakia and Turkey - for episodes of flexible exchange rate policies. In this endeavor, we have recourse to the event study approach, which is claimed to be superior to econometric analysis if interventions take place only sporadically (Fatum, 2002, and Fatum and Hutchison, 2003).

In addition to the broad country coverage, our contribution to the literature is threefold. First, we scrutinize the role of central bank communication and interest rate news and study how they can

1 For a survey, see e.g. Sarno and Taylor (2001).

2 Turkey and the Czech Republic are the two countries for which daily FX interventions are analyzed most extensively. For Turkey, see Domac and Mendoza (2004), Guiamaraes and Karacadog (2004) and Akinci et al. (2005a,b). For the Czech Republic, examples are Disyatat and Galati (2005), Égert and Komárek (2006) for daily data and Geršl and Holub (2006) for monthly and daily data. Scalia (2006) matches daily intervention data with intraday koruna/euro data. Gereben, Gyomai and Kiss (2006) study FX interventions in a FX microstructure (order flow) setup for Hungary. While not directly linked to the issue of the effectiveness of FX interventions, it is worth noting that Radulescu (2004) and Chmelarova and Schnabl (2006) estimate reaction functions of central bank interventions for Romania and Croatia, respectively. 
reinforce the effect of actual interventions. Second, we do not only analyze the effectiveness of FX interventions, but also attempt to clarify whether actual interventions are fully, partially or not at all sterilized. This is crucial, given that unsterilized interventions are thought to be more effective than sterilized interventions. We also discuss under what conditions unsterilized interventions are more effective than sterilized ones. Finally, the success of central bank interventions is interpreted not only in terms of the statistical success criteria but also in the light of the officially stated objectives of FX interventions.

The remainder of this study is structured as follows. Section 2 briefly sketches the role and stated objectives of FX interventions in the countries under review. Section 3 discusses the event study approach, while section 4 describes the dataset and section 5 presents the results. Section 6 analyzes whether FX interventions are fully sterilized. Section 7 finally gives some concluding remarks.

\section{Foreign Exchange Interventions in Emerging European Countries}

\subsection{Exchange Rate Regimes and Foreign Exchange Interventions}

Generally speaking, monetary policy in the transition economies of Central and Eastern Europe relied on the exchange rate as an intermediate target to achieve price stability in the early stages of the transition process. The exchange rate was considered the most effective channel of monetary policy, as the monetization of the economy was relatively low, which implied that the interest rate channel and the credit channel were not considered particularly effective. Hence, stable nominal exchange rates anchored domestic inflation by keeping the price of imported tradable goods stable. Furthermore, and perhaps more importantly, stable exchange rates provide a nominal anchor for inflationary expectations both in the tradable and the nontradable sectors.

At a later stage of transition, the countries under review took different approaches with regard to the exchange rate regime, although there seems to be a general move toward more exchange rate flexibility (see Table 1). Five out of the six surveyed countries currently operate managed float 
regimes. While de facto exchange rate flexibility is highest in the Czech Republic, it is lowest in Croatia. In fact, the exchange rate fluctuations observed in Croatia are comparable to that in Hungary, where a fixed regime with a wide band is in place.

Pegged regimes were mostly maintained by restrictions on capital movements and less by exchange rate interventions on the rather illiquid FX markets. However, restrictions on capital movements were gradually levied from 1994 onward, because the countries wished to join the OECD and the European Union and because of IMF recommendations. As a matter of fact, one important reason for the shift toward more exchange rate flexibility was capital account liberalization, followed eventually by considerable cross border capital in- and outflows. Some countries frequently used - and still use - FX interventions to achieve the central banks' policy objectives, which we will outline in greater detail below.

Table 1. Exchange rate regimes in transition economies and in Turkey, 1990-2006.

\begin{tabular}{lccccccccccccccccc}
\hline \hline & '90 & '91 & '92 & '93 & '94 & '95 & '96 & '97 & '98 & '99 & '00 & '01 & '02 & '03 & '04 & '05 & '06 \\
\hline Croatia & & & 1 & 6 & 6 & 6 & 6 & 6 & 6 & 6 & 6 & 6 & 6 & 6 & 6 & 6 & 6 \\
Czech Rep. & 1 & 1 & 1 & 1 & 1 & 1 & 5 & $5-6$ & 6 & 6 & 6 & 6 & 6 & 6 & 6 & 6 & 6 \\
Hungary & 1 & 1 & 1 & 1 & 1 & $1-2$ & 2 & 2 & 2 & 2 & 2 & $2-4-5$ & 5 & 5 & 5 & 5 & 5 \\
Romania & 1 & 3 & 3 & 3 & 3 & 3 & 3 & 3 & 3 & 3 & 3 & 3 & 3 & 3 & $3-6$ & 6 & 6 \\
Slovakia & 1 & 1 & 1 & 1 & 1 & 1 & 5 & 5 & $5-6$ & 6 & 6 & 6 & 6 & 6 & 6 & 6 & 6 \\
Turkey & 3 & 3 & 3 & 3 & 3 & 3 & 3 & 3 & 3 & 3 & 2 & 6 & 6 & 6 & 6 & 6 & 6 \\
\hline \hline
\end{tabular}

1: peg to a currency or to a basket with fluctuation margins less than or equal to $\pm 2.25 \%$

2: crawling peg with fluctuation margins of less than or equal to $\pm 2.25 \%$

3: float with active management by monetary authorities (implicit crawling peg)

4: crawling peg with fluctuation margins of more than $\pm 2.25 \%$

5: peg to a currency or a basket with fluctuation margins of more than $\pm 2.25 \%$

6: float with intervention

\subsection{Official Objectives and Instruments of FX Interventions}

This section presents the officially announced objectives and the instruments of FX interventions, which we extracted from various central bank publications (see Appendix A for the sources). Let us start with Croatia: The Croatian National Bank (HNB) has been regularly intervening on the 
FX market since 1994 by means of FX auctions, with the objective to stabilize the kuna against the euro (German mark prior to 1998 ) in a band of $\pm 2 \%$.

After the 1997 crisis, the Czech National Bank intervened directly on the interbank FX market in both directions in order to stabilize the exchange rate against the German mark and announced a target band of 17-19.5 CZK/DEM (33.5-38.5 CZK/EUR). Since the introduction of direct inflation targeting in 1998, interventions aimed to slow down the nominal currency appreciation. They were justified to avoid major deviations of the exchange rate from its fundamentals. No interventions took place between 2003 and mid-2006.

Since the enlargement of the bands to $\pm 15 \%$ in May 2001, the Hungarian central bank intervened twice, on January 15 and 16, 2003, with the deliberate aim of preventing the forint from appreciating beyond the stronger edge of the band. ${ }^{3}$ The central bank was present on several other occasions on the FX market, not because it intended to influence the exchange rate, but for the purposes of buying foreign currency on behalf of the government to service FX denominated public debt and because it was selling off the FX reserves accumulated after the markets had calmed down following the speculative run on January 15-16, 2003.

In Romania, frequent interventions were replaced by punctual interventions following the move to adopt a managed float in November 2004. The National Bank of Romania conducted FX interventions to prevent an excessive appreciation of the domestic currency on the one hand, and to build up foreign exchange reserves on the other.

During the years following the move to adopt a managed float, the Slovak central bank's FX interventions aimed to achieve two goals: to diminish the excessive volatility of the Slovak koruna's exchange rate against the German mark (and against the euro after 1999), and to counteract appreciation pressures from 2002 onward.

According to the Central Bank of the Republic of Turkey (CBRT), foreign exchange interventions are not intended to target any precise exchange rate level, but aim to dampen excessive

3 See Érsek (2005) for a case study of the speculative attack against the forint. 
volatility instead and to increase international reserves. When considering exchange rate volatility, the central bank not only looks at past and present volatilities, but also considers changes in volatility that are expected to occur in the future (CBRT, 2004, paragraph 26). FX interventions by the Turkish central bank can take the form of discretionary interventions carried out on the FX market, which are made public some time after the interventions took place, or with commercial banks and pre-announced FX auctions. The declared goal of the FX auctions was changed over time, as they are not intended to decrease FX volatility, but rather to build up FX reserves in accordance with the monetary policy framework (international reserves are an intermediate target) without influencing the exchange rate. ${ }^{4}$

Table 2. Officially announced objectives of central bank interventions

\begin{tabular}{lll}
\hline \hline \multicolumn{1}{c}{ Year } & \multicolumn{1}{c}{ Objective } \\
\hline Croatia & $1994-$ mid-2006 & Stabilizing the kuna in a band of about $\pm 2 \%$ within a managed float. \\
Czech Rep. & $\begin{array}{l}1997-1998 \\
1999-2002 \\
2003-\text { mid-2006 }\end{array}$ & $\begin{array}{l}\text { Stabilizing the koruna vis-à-vis the German mark after the koruna crisis } \\
\text { Smoothing the trend appreciation of the exchange rate } \\
\text { No FX interventions }\end{array}$ \\
\hline Hungary & 2003 & Interventions at the stronger margin to defend the exchange rate regime \\
\hline Romania & $11 / 2004-$ & $\begin{array}{l}\text { Building up FX reserves } \\
\text { Counteracting appreciation pressures of the Romanian leu }\end{array}$ \\
\hline Slovakia & $1998-2005$ & $\begin{array}{l}\text { Decreasing excessive exchange rate volatility } \\
\text { Counteracting appreciation pressures on the Slovak koruna }\end{array}$ \\
\hline Turkey & $2002-2005$ & $\begin{array}{l}\text { Preventing excessive exchange rate volatility (discretionary interventions) } \\
\text { Building up FX reserves (pre-announced FX auctions) }\end{array}$ \\
\hline \hline
\end{tabular}

4 However, reading between the lines suggests that decreasing excessive exchange rate volatility is perhaps not the key goal of the central bank and that it might actually consider altering the trend of the exchange rate. According to CBRT (2002, p. 74), "foreign exchange auctions were temporarily suspended as of July due to the volatilities of exchange rates", which is in contradiction to the declared intention of counteracting excessive volatility. It is also mentioned several times that the central bank considers excessive volatility in both directions. This may indicate that the CBRT also looks at changes in the exchange rate, given that volatility is an absolute measure. 
Table 3. Types of FX interventions

\begin{tabular}{lll}
\hline \hline & \multicolumn{1}{c}{ Instruments } & \multicolumn{1}{c}{ Announcement } \\
\hline Croatia & FX auctions & On the morning prior to the auction \\
\hline Hungary & Direct interventions on the FX market & After the intervention; in central bank publications \\
\hline Romania & Direct interventions on the FX market & $\begin{array}{l}\text { After the intervention, until early 2005 in } \\
\text { monthly bulletins, since then no official publication }\end{array}$ \\
\hline Slovakia & Direct interventions on the FX market & After the interventions; one month later \\
\hline Turkey & Direct interventions on the FX market & $\begin{array}{l}\text { Direct interventions: published 3 months later } \\
\text { Pre-announced FX auctions }\end{array}$ \\
\hline \hline
\end{tabular}

\subsection{Off-Market Interventions}

A number of central banks resorted to off-market FX operations. These preventive actions aimed to avoid that the conversion of large privatization revenues to the domestic currency takes place on the foreign exchange market by putting appreciation pressure on the national currency. Therefore, central banks converted privatization revenues and deposited them in domestic currency on a special account at the central bank held usually by the Ministry of Finance or the privatization authority, e.g. in Croatia (privatization of Croatian Telecom in 2001 and INA, a Croatian oil company, in 2003), in the Czech Republic in 2000 and 2002 and, more recently, in Slovakia.

\section{The Effectiveness of FX Interventions: An Event Study Approach}

\subsection{Methodological Issues}

If foreign exchange interventions occur rarely or only after a large number of days without intervention, standard time series econometric techniques are likely to find that official interventions do not have an effect on exchange rates, with the latter being highly volatile in the short run (Fatum, 2002; Fatum and Hutchinson, 2003). A big advantage of the event study approach over time series techniques is that it only looks at periods when interventions take place, and is thus able to filter out longer periods during which no interventions happen and which might cause econometric studies to find no relation between foreign exchange interventions and exchange rate behavior. 
From our group of six countries, the literature covers mostly only the Czech Republic and Turkey, and a majority of the papers use econometric estimations. Only Akinci et al. (2005b) and Geršl and Holub (2006) employ the event study approach for Turkey and the Czech Republic, using daily and monthly data, respectively. ${ }^{5}$

When applying the event study approach, we have to address the following three issues: the definition of a single intervention episode or event, its effectiveness and the time horizon analyzed before and after the intervention event.

\subsubsection{The definition of a single intervention episode or event}

The key question in this context is how many days between two single intervention acts going in the same direction (both purchases or both sales) qualify them as two distinct intervention events. ${ }^{6}$ In this study, we considered the following five alternative definitions of an intervention event: the number of consecutive days without intervention activity between single interventions in one direction can be up to 2, 5, 10, 20 and 30. An intervention event ends if more than 2, 5, 10, 20 or 30 days go by without an intervention or if the intervention is in the opposite direction. ${ }^{7}$

\subsubsection{The effectiveness of an intervention event}

The following two classes of effective interventions can be distinguished.

Leaning against the wind (breaking/reversing the trend): central bank intervention reverses the trend of the exchange rate, i.e. the exchange rate depreciates (appreciates) in the pre-event window, and appreciates (depreciates) in the post-event window following domestic currency purchases (sales).

5 For Turkey, Domac and Mendoza (2004) use daily data from February 2001 to May 2002 and rely on an EGARCH model. Guimaraes and Karacadag (2004) apply the component GARCH model for a two-year period running from March 2001 to October 2003. Using a very similar period (March 2001 to May 2003), Akinci et al. (2005a) carry out time-varying estimations, and Akinci et al. (2005b) use a simple GARCH model. For the Czech Republic, Disyatat and Galati (2005) report estimation results of an instrumental variable approach for the period 2001 to 2002. 6 For a discussion, see Fatum (2000).

7 Fatum (2000) and Fatum and Hutchison (2003) use up to 15 days, while Cashin et al. (2006) use up to 10 days with no intervention between two consecutive interventions within a single event. 
Buying domestic currency: $\left(I_{t}<0, \Delta e_{t-}>0\right.$ and $\left.\Delta e_{t+}<0\right)$

Selling domestic currency: $\left(I_{t}>0, \Delta e_{t-}<0\right.$ and $\left.\Delta e_{t+}>0\right)$

Where $I_{t}<0\left(I_{t}>0\right)$ stands for domestic currency purchases (sales), $\Delta e_{t-}\left(\Delta e_{t+}\right)$ is the change in the exchange rate in the pre-event window (post-event window). ${ }^{8}$

Smoothing exchange rate movements: the central bank slows down the appreciation or the depreciation of the domestic currency, i.e. domestic currency purchases (sales) cause the exchange rate to depreciate (appreciate) less in the post-event window than in the pre-event window. ${ }^{9}$

Domestic currency purchases: $\left(I_{t}<0, \Delta e_{t-}>0, \Delta e_{t+}>0\right.$ and $\left.\Delta e_{t+}<\Delta e_{t-}\right)$

Domestic currency sales: $\left(I_{t}>0, \Delta e_{t-}<0, \Delta e_{t+}<0\right.$ and $\left.\Delta e_{t+}>\Delta e_{t-}\right)$.

\subsubsection{The time horizon analyzed before and after the intervention event}

As to the size of the pre- and post-event windows, we look at nine different lengths: 1, 2, 5, 10, $15,20,30,40$ and 60 days. The pre- and post-event windows are constructed in a symmetric way, implying that 2-day (5-day etc.) pre-event windows are compared to 2-day (5-day etc.) post-event windows. ${ }^{10}$ In addition, effectiveness is also analyzed for the event window itself, if the event window's size is larger than two days using a pre-event window of two days.

It is important to look at pre- and post-event windows that do not overlap with other interventions events, as the latter could modify the effect of the intervention event under consideration.

8 The exchange rate is expressed as domestic currency units over one unit of foreign currency. Hence, an increase (decrease) denotes depreciation (appreciation).

9 A third variant would be "leaning with the wind", if the central bank accentuates market trends (increasing the pace of appreciation/depreciation). However, in view of the official goals of FX interventions of the countries under study, leaning with the wind can be regarded as a failure rather than a success. Note that the literature (e.g. Fatum, 2000 and Fratzscher, 2005) also uses the event criterion and the direction criterion, which analyze whether the exchange rate moves in the desired direction in the event window (event criterion) or after the event (direction criterion). However, these two criteria are not very meaningful, given that the development of the exchange rate prior to the intervention event is not considered. In addition, our definition of exchange rate smoothing is stricter than the one used in the literature. Our definition of exchange rate smoothing implies that interventions slow down the pace of depreciation or appreciation, but do not reverse the trend, while exchange rate smoothing as it is generally defined in the literature encompasses - somewhat confusingly - both exchange rate smoothing and leaning against the wind as defined in our paper.

10 Fatum (2000) employs 2-, 5-, 10-, and 15-day window sizes, while Cashin et al. (2006) looks at 2-day and 21-day windows. Cashin and others term the 2-day window short-term and the 21-day window long-term windows. 
Finally, we analyze not only changes in the exchange rate, but also focus on changes in the volatility of the exchange rate. For this purpose, we compare the volatility measures over the (symmetric) pre- and post-event windows, but ignore pre- and post-event windows of one and two days as standard deviations; our measure of volatility cannot be meaningfully computed for such short periods.

\subsection{Statistical Test of Effectiveness}

Effectiveness of individual intervention events can be statistically analyzed using the non-parametric sign test, which has been frequently used in event studies (MacKinley, 1997, p. 32) and in the literature on FX interventions of recent years (Humpage, 1999; Fatum, 2002, 2005; Fatum and Hutchison, 2003; and Fratzscher, 2005). The test statistic is constructed as follows: $S=\left(\frac{N^{+}}{N}-\mu\right) \frac{\sqrt{N^{+}}}{N}$, where $N^{+}$is the number of successful events, is the total number of events analyzed, $\mu$ is a probability parameter and $S \sim N(0,1)$. There is indeed a probability of $50 \%(\mu=0.5)$ that the exchange rate will appreciate (depreciate) in the period $t+1$ as compared to a depreciation (appreciation) in period t. Hence, the non-parametric sign test investigates whether the number of leaning-againstthe-wind type of successes is significantly larger than $50 \%$. In other words, the sign test examines whether the null hypothesis of a random change in the exchange rate can be rejected against the alternative of a systematic change (due to FX interventions in our case). In a similar vein, the probability of the exchange rate depreciating (appreciating) less but not switching to an appreciation (depreciation) in the case of exchange rate smoothing is $25 \%(\mu=0.25) .{ }^{11,12}$

\subsection{The Key Interest Rate and Verbal Interventions}

An interesting question is whether changes in the exchange rate occur only as a result of FX interventions or because other factors also interfere with the impact of FX interventions. The key interest rate and verbal intervention by the central bank play a prominent role in this respect, as FX

\footnotetext{
11 When exchange rate smoothing is defined as including leaning against the wind, the probability parameter takes the value of 0.75 ( 0.5 for leaning against the wind plus 0.25 for exchange rate smoothing).

12 Note that finite sample critical values are used for the nonparametric sign tests.
} 
interventions possibly turn out to be effective partly because they are supported by key interest rate moves (Fatum and Hutchison, 2003) and/or by verbal interventions of the central bank (Fratzscher, 2005).

To see the extent to which key interest rate moves and verbal interventions interfere with actual FX interventions, it is necessary to construct intervention events during which no moves in the domestic or foreign key interest rate and verbal interventions occur. In addition, the condition of having no overlap in the pre- and post-event windows with other intervention episodes has to be extended in such a way that the pre-and post-event windows contain neither other intervention episodes nor any interest rate step and verbal interventions.

It is also relevant for our purposes to disentangle the effect of pure interest rate moves (net of actual and verbal interventions) and pure verbal interventions (net of actual interventions and interest rate moves) on the exchange rate. Against this backdrop, we construct so-called interest rate and verbal intervention events, using the same event and pre- and post-window definitions as for the FX intervention events. The success of the measures is evaluated as follows:

Leaning against the wind: a domestic interest rate cut (hike) or an increase (decrease) in the foreign interest rate causes exchange rate depreciation (appreciation) instead of the appreciation (depreciation) observed in the pre-event window. Verbal intervention is regarded as successful, if supportive (weakening) intervention causes the exchange rate to appreciate (depreciate) following exchange rate depreciation (appreciation) in the pre-event window.

Smoothing exchange rate movements: a domestic interest rate cut (hike) leads to less appreciation (depreciation) in the post-event window than in the pre-event window. Similarly, increases (decreases) in the foreign interest rate bring about less appreciation (depreciation) after the event. Verbal intervention is considered successful, if supportive (weakening) intervention causes the exchange rate to depreciate (appreciate) less following exchange rate depreciation (appreciation).

Finally, the joint effect of actual interventions on the one hand, and interest rate moves and verbal interventions on the other hand, obviously depends upon the coordination of the different 
policy measures. Table 4 below indicates the direction of interest rate moves and verbal interventions, which are consistent with actual interventions.

Table 4. Interest rate moves and verbal interventions consistent with actual interventions

\begin{tabular}{lll}
\hline \hline & Domestic currency weakening & Domestic currency strengthening \\
\hline FX interventions & Domestic currency sale & Domestic currency purchase \\
Domestic interest rate & Decrease & Increase \\
Foreign interest rate & Increase & Decrease \\
Verbal intervention & Weakening statement & Strengthening statement \\
\hline \hline
\end{tabular}

\section{Sterilization of FX Interventions}

It is common wisdom that non-sterilized FX interventions are effective because changes in the liquidity of the banking sector are transmitted to money supply and the nominal exchange rate changes owing to a shift in relative money supplies. Against this background, it is important to explore whether interventions are sterilized in the countries considered. If we turn to official central bank publications, they confirm that FX interventions are indeed sterilized in the countries under study by means of standing facilities and/or open market operations, with a shift being observed toward open market operations in recent years. ${ }^{13}$ In addition, Croatia actively uses administrative measures (including changes in the calculation base of minimum reserve and marginal reserve ratios) to withdraw excess liquidity from the interbank money market. A number of other central banks have been sterilizing excess liquidity resulting from the decrease of the minimum reserve requirement ratio in the attempt to approach the level prevailing in the euro area ( $2 \%$ in 2006).

Nevertheless, it is very difficult to determine whether FX interventions are fully or only partially sterilized, because the sterilization of FX interventions is part of the central bank's overall liquidity management. In addition to monetary policy operations and changes in the reserve requirement

13 For instance, the Romanian central bank employs deposit facilities and increasingly relies on open market operations including certificates of deposits and fixed-rate deposit auctions. The Croatian and Slovak central banks use central bank bill auctions. In Turkey, the central bank regulates liquidity via deposit-buying auctions and via reverse repos at the Istanbul Stock Exchange. 
system, the liquidity of the banking system (i.e. the current account holdings of commercial banks at the central bank) is to a large degree influenced by so-called autonomous liquidity factors, which are not controlled by the central bank. These autonomous factors are, among others (i) money in circulation, (ii) the redemption of maturing government securities or (iii) the issuance of new government securities, (iv) the use of the privatization revenues deposited at the central bank, and (v) the in- or outflow of foreign capital excluding FX interventions. The phenomenon of dedollarization, which can be observed in the Turkish economy after 2002, also plays a role in this context.

Full sterilization by the central bank is not necessary, if changes in the autonomous factors absorb the excess liquidity created by domestic currency sales or create liquidity that is destructed by domestic currency purchases. In this case, the central bank should take care only of the "remaining" excess liquidity or of the liquidity to be created. In contrast, full sterilization may be not enough, if the evolution of autonomous factors amplifies the effect of FX interventions. In this case, the central bank needs to sterilize beyond the amount of the FX intervention.

Central banks make projections or forecasts of the autonomous factors. These forecasts are essential for monetary policy operations to obtain the desired level of liquidity. However, autonomous factors are rather volatile and admittedly difficult to forecast with accuracy. Consequently, while FX interventions can be fully sterilized (including both monetary policy operations and changes in the autonomous factors) ex ante, the sterilization may be only partial or disproportionate ex post to the extent that the forecasts have been imprecise. This implies that proportionate sterilization is very difficult to achieve in practice. This problem is particularly relevant in transition and emerging market economies, given the possibly large forecasting errors due to short time series with multiple structural breaks. Furthermore, it is impossible to assess the reviewed central banks' forecasting ability - as opposed to the ECB and the Bank of Japan, they do not publish liquidity forecasts (Bindseil, 2002), and little is known about their projection and forecasting methods. ${ }^{14}$ To

14 Some central banks rely only on expert opinion in the management of interbank liquidity. 
this adds the high degree of uncertainty regarding the pace of, and the difficulty to forecast, the de-dollarization process in Turkey.

Hence, the practical question is not whether a central bank fully sterilizes its interventions, but rather whether it manages to absorb significant amounts of excess liquidity or compensate a fall in liquidity caused by FX interventions. To show the extent of sterilization, we collected monthly data on the evolution of central bank sterilization from central bank balance sheets and compared them to the number of FX interventions. ${ }^{15}$ Figure 1 shows that central bank interventions were largely offset by sterilization operations in the Czech Republic, Hungary and Slovakia, while sterilization was only partial in Croatia, Romania and Turkey. However, as argued earlier, sterilization operations have to be analyzed jointly with the development of the autonomous factors.

Consequently, unsterilized or only partially sterilized interventions should show up in the monetary base and, most importantly, in monetary aggregates such as for example M2. In fact, the monetary base remains stable for all countries except for Croatia and Hungary. In Hungary, there is a spike in the monetary base despite sterilization. This is because sterilization is achieved via standing facilities (central bank deposits), which are included in the monetary base. By contrast, open market operations (OMOs) are not included in the monetary base. Therefore, for countries relying largely on OMOs as a tool of sterilization, there is no change in the monetary base. However, classification also matters: Even though standing facilities make up the major part of sterilization operations in Romania, sterilization is not reflected in the monetary base, probably because the monetary base excludes standing facilities (publication of the National Bank of Romania do not provide help on this issue).

$15 \quad$ Daily data would be needed to see whether individual FX interventions are fully sterilized. They are available for monetary policy operations, but not for the autonomous factors, which are crucial to assess whether FX interventions are fully or only partially sterilized by monetary policy operations. It might also be argued that, if interventions were fully sterilized, interest rates would remain unchanged because no changes would take place in the money supply. By contrast, interest rates would move, if sterilization was not or only partially sterilized. However, such an approach potentially underestimates the true number of sterilized interventions because of the time-varying risk premium. For instance, if the central bank intervened by selling the domestic currency to counteract appreciation pressures, it could also decrease the interest rate and at the same time sterilize the full amount of FX interventions, if the decrease in the policy rate reflected a drop in the country risk premium. 
However, changes in the monetary base need not be fully reflected in the monetary aggregates, given that standing facilities, a major part of the monetary base, are not included in the monetary aggregates. Indeed, monetary aggregates remain fairly stable in the presence of FX interventions in all countries (including Hungary) except for Croatia, where an inspection of Figure 1 below suggests that M4 might be affected by FX interventions. Based on the national banks' data presented below, we conclude that Croatia is the only country where FX interventions have an obvious effect on the monetary aggregates and hence are unsterilized. In the other countries reviewed, FX interventions do not have a clear effect on the monetary aggregates and are therefore probably mostly sterilized. ${ }^{16}$

16 The relationship between FX interventions and monetary aggregates could be analyzed in a formal way. However, such an exercise is out of the scope of this paper. 
Figure 1. FX interventions, sterilization and monetary aggregates (in NCU millions)
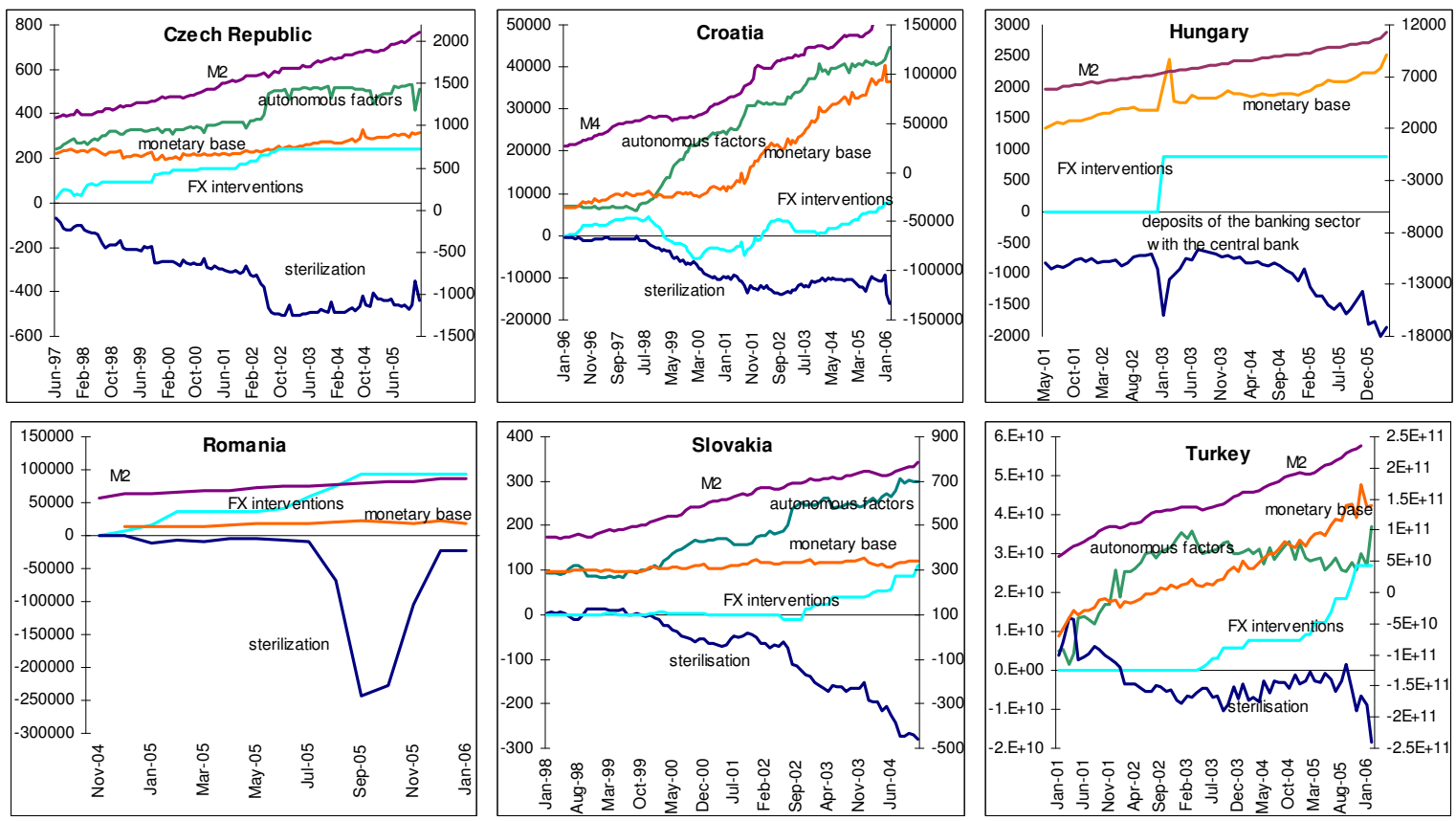

Source: Various publications of the national central banks.

Notes: The series are cumulated. FX interventions are expressed in national currency units (NCU) to render them comparable to monetary aggregates. The amount of sterilization is given as the sum of monetary policy factors from the monetary base (taken from the asset and liability side of the central bank's balance sheet), i.e. the sum of central bank standing facilities and open market operations. Negative (positive) figures indicate that liquidity is taken out from (added to) the system. Data on autonomous factors, the monetary base and monetary aggregates were drawn from central bank publications. M2 is taken as a measure of monetary aggregate. For Croatia, only M4 is available.

\section{Description of the Data}

The effectiveness of interventions is analyzed for the period during which the countries under study were operating flexible exchange rate regimes and for which daily data are available. Our sample starts on January 4, 1996, for Croatia, on June 1, 1997, for the Czech Republic, on April 4, 2001, for Hungary, on November 1, 2001, for Romania, on January 4, 1999, for Slovakia and on February 22, 2001, for Turkey. The observation period ends on January 31, 2006.

Daily exchange rate data are collected vis-à-vis the foreign currency to which the respective country's exchange rate policy is oriented: the euro (German mark prior to 1999) for Croatia, the 
Czech Republic, Hungary, Romania and Slovakia and the dollar for Turkey. The exchange rate series are obtained from the ECB (via Datastream) for the Czech Republic, Hungary, Romania and Slovakia. The data source is Datastream for Turkey ${ }^{17}$ and the Croatian National Bank for Croatia. As the Croatian National Bank publishes exchange rate data with a delay of two days, the data series for Croatia had to be adjusted for this two-day lag. The data retrieved from the ECB is based on exchange rate fixing at 13.30, while the time of fixing is not known for Croatia and Turkey.

Data on daily FX interventions is obtained from the central bank for Croatia, the Czech Republic, Hungary and Turkey. ${ }^{18}$ Time series used for Slovakia and Romania are a mixture of daily and monthly data. Monthly FX interventions reported in central bank publications are refined and completed by daily FX interventions reported in Factiva. ${ }^{19}$ Monthly interventions are treated as daily interventions throughout the given month. It should be noted in this context that what is important in the event study approach is not the size of the intervention, but the fact that it takes place on a given day.

Interest rate data refer to changes in the key central bank interest rate. ${ }^{20}$

Verbal intervention data with a daily frequency are extracted from news reports obtained from Factiva. ${ }^{21}$ In a first step, a search is conducted in Factiva's archives to identify central bank statements concerning the exchange rate. For each country, the search is carried out using the following words in the following combination: "exchange rate" AND name of the national currency (e.g. forint, koruna, kuna, leu, lira) AND ("central bank" OR "intervention" OR name of the central bank governor). Official statements by government officials (including the prime minister, the

17 The following Datastream codes are used: CZECBSP for the Czech Republic, HNECBSP for Hungary, SXECBSP for Slovakia, RMECBSP for Romania, and TKUSDSP for Turkey.

18 Diverse central bank publications downloaded from central bank websites or obtained upon request.

19 Factiva, a Dow Jones and Reuters Company, provides a collection of sources on business news and information. It includes, among others, Dow Jones and Reuters newswires.

20 Czech Republic: two-week REPO rate; Hungary: two-week deposit rates at the central bank; Romania: open markets operations reference rate; Slovakia: discount rate until end-2001, two-week REPO tender rate after January 1, 2002; Turkey: one-week borrowing facility; ECB: refinancing rate: fixed rate tender rate until June 27, 2000, and variable rate tender rate after June 28, 2000; US: federal funds rate. Note that for Turkey, data on policy rates start on April 25, 2003.

21 See Fratzscher (2005) for a discussion on the use of verbal intervention data collected from newswires. 
minister of finance or any other minister) are purposefully omitted, given that decisions with regard to FX intervention and to interest rate moves are the exclusive domain of the central banks in the countries under study. Subsequently, the central bank statements need to be classified as to whether they aim at strengthening or weakening the currency. Since this classification of central bank statements to some extent also depends on subjective perception, those statements which are not very clear with regard to their intention (to support or undermine the national currency) are eliminated. Only statements with a rather straightforward message are used. Finally, it should be mentioned that news reported after 13.30 are assigned to the next day, given that the exchange rate data is based on a fixing at 13.30.

Figure 2. Actual and verbal interventions, interest rate moves and the exchange rate
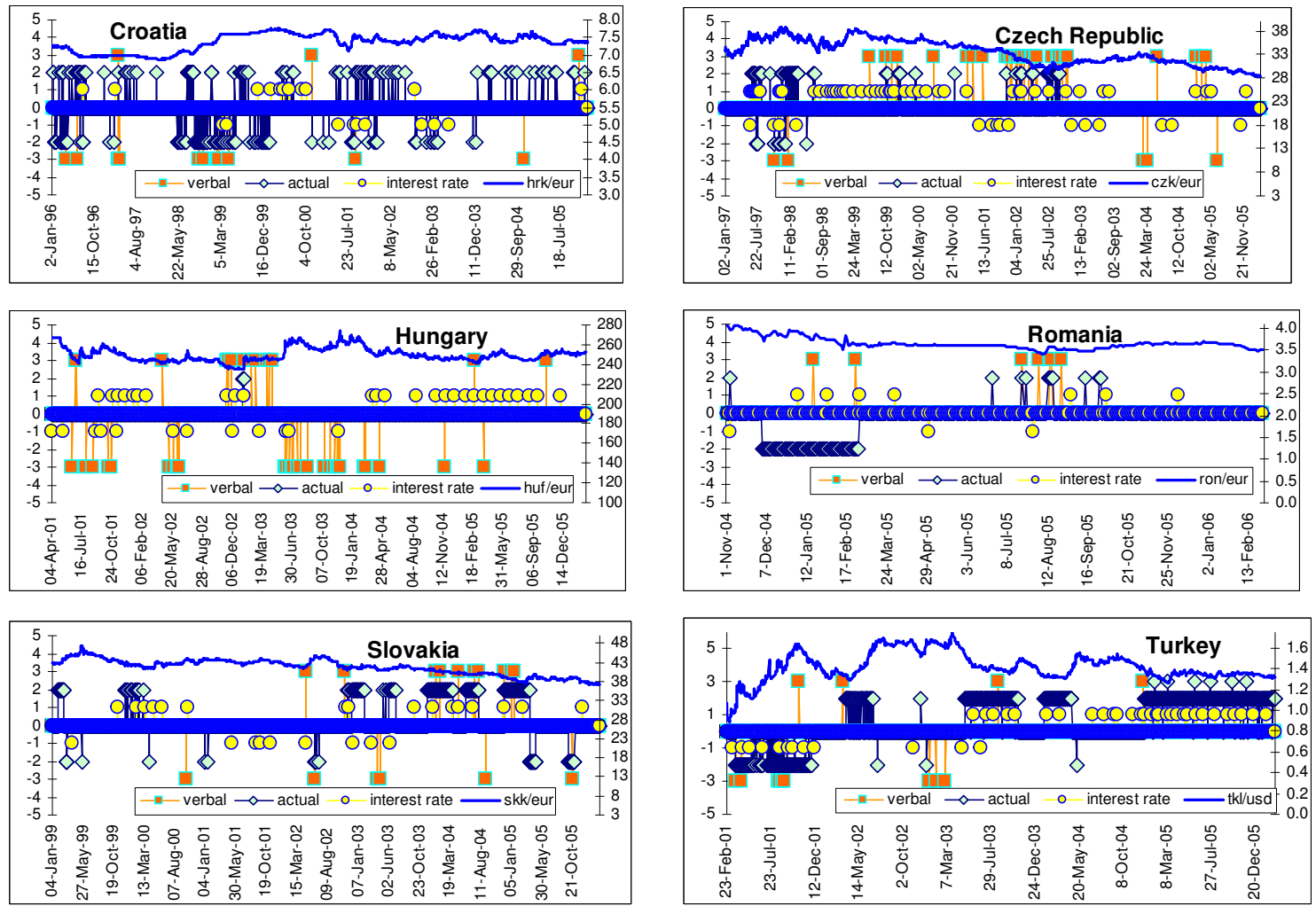

Note: The right-hand scale denotes the exchange rate. Negative (positive) figures refer to interventions and interest rate moves, which strengthen (weaken) the domestic currency. 


\section{Results}

\subsection{Net Effect of FX Interventions - Overall Impact}

The first step of our analysis is to look at the effect of actual interventions on the exchange rate. To obtain the net effect of actual interventions, we have to ascertain that overlaps with verbal interventions and interest news are filtered out. Therefore, intervention events are constructed so that they do not include any verbal interventions or interest rate news. Consequently, the evaluation and the comparison of the pre-event and the post-event windows consider only those windows, which do not contain any verbal interventions or interest rate news. In addition, pre- and post-event windows are not allowed to overlap with previous or following intervention events. In other words, if there is a verbal intervention/interest news/actual intervention event in $\mathrm{t}-14$ preceding a given intervention event, only the 1-, 2-, 5- and 10-day pre- and post-event windows are studied. If, in addition, there is any verbal intervention/interest news/intervention event in, say, $t+9$ following the same intervention event, the analysis is restricted to the 1-, 2- and 5-day windows, given that larger windows are contaminated by the effect of other types of information. A practical consequence of this is that the number of longer pre- and post-event windows without overlaps drops dramatically or even to zero in some cases, which makes it impossible to analyze the effectiveness of actual interventions for some of the windows in some countries (see Appendix).

For Turkey, two intervention series are analyzed. In the first series, we consider only discretionary interventions, because the central bank asserted in a number of statements and publications that FX auctions were not intended to influence the exchange rate but used to build up foreign exchange reserves. However, because FX auctions were carried out during long periods of time with large numbers of foreign exchange transactions, we also employ intervention data, which combine discretionary and FX auction interventions.

For the Czech Republic, the investigated period ends in end-2002, given that no interventions took place after 2002 . 
Given that the Hungarian central bank simultaneously used actual and verbal interventions and the interest rate instrument during the only intervention episode in January 2003, we found no preand post-event windows without overlap. Therefore, the net effect of actual interventions on the exchange rate cannot be assessed for this country.

The results of the non-parametrical sign test show weak or nonexistent effects of aggregate actual interventions on the exchange rate (see Appendix). The reported p-values clearly indicate that actual interventions do not have a significant influence on the exchange rate in Romania and Turkey. In the Czech Republic, the results are sensitive to the definition of the intervention event with regard to the number of days that passed with no intervention activity between two individual intervention acts: while leaning against the wind for the 2-day pre- and post-event window is detected at the $10 \%$ significance level with the 10-, 20- or 30-day event definition, interventions seem to have no systematic influence on the exchange rate with the 2- and 5-day event definitions. In Croatia, the results are similarly sensitive to the event definition between 1996 and 2006. Although all event definitions yield significant results for the 10-day pre- and post-event window size if we analyze only the second half of the sample, i.e. 2001 to 2006, the type of the success remains questionable (exchange rate smoothing or leaning against the wind). For Slovakia, a robust leaning against the wind effect is detected for the 10-day window.

\subsection{Net Effect of FX Interventions: Does Direction Matter?}

Thus far, we have analyzed the combined effect of domestic currency sales and purchases. Now we will focus on the effectiveness of separate sales and purchases. The results are summarized in Table 5; they provide more evidence of successful interventions than the aggregated intervention data.

Actual interventions are found to be successful to slow down or even reverse the appreciation of the domestic currency at shorter time horizons. For instance, domestic currency sales in Croatia turned appreciation into depreciation at the 2- and 10-day horizon, while similar effects are found in the Czech Republic for the 1- and 2-day pre- and post-event windows. In Turkey, only discretionary 
lira-sale interventions had a significant impact on the exchange rate by reversing appreciation, whereas the combination of discretionary and FX auction-based interventions was ineffective. For Slovakia, the results indicate that koruna sales systematically led to exchange rate smoothing at the 1-, 2- and 5-day time horizons. Contrary to the other countries, it was not possible to analyze the effectiveness for pre- and post-event windows beyond 5 days owing to overlaps with other intervention episodes, verbal interventions and interest rate news.

In contrast, in the fight against currency depreciations, domestic currency purchases turn out to have a significant impact on the exchange rate only in Slovakia. For this country, significant leaning against the wind effects are detected in particular for the 5-day pre- and post-event window.

\subsection{Net Effect of Verbal Interventions and Interest Rate News}

In order to assess whether verbal interventions or changes in the key interest rate are capable of inducing systematic changes in the exchange rate, we used individual observations on verbal interventions and on policy rate changes to construct events. We would like to single out the net effect of verbal interventions and interest news; hence, verbal intervention events are not allowed to contain interest rate news and actual interventions. Similarly, interest news events do not include verbal and actual interventions. Furthermore, only those pre- and post-event windows are considered in which no actual or verbal intervention and interest news occurred.

The results are fairly striking (see Table 5). Interest news adjusted for actual and verbal interventions have no effect on the exchange rate in Croatia, Romania, Slovakia and Turkey. Policy rate changes were able to smooth the exchange rate, but not to reverse the trend in the Czech Republic and Hungary at the 20-day and 30-day horizons, respectively, but only when they were used to counteract exchange rate appreciation.

Verbal interventions adjusted for actual interventions and interest news were not effective in

all countries except Hungary, where very short-term effects could be identified for those cases in which central bank communication aimed at weakening appreciation pressures. 


\subsection{Combined Effect of Actual and Verbal Interventions and Interest Rate News: Overall Impact}

Having studied the net effect of actual and verbal interventions and interest rate news, we now focus on the combined effect of these three factors on the exchange rate. We set out to answer this intriguing question by constructing actual intervention events without eliminating verbal interventions and interest news. At the same time, pre- and post-event windows are allowed to include verbal interventions and policy rate changes. However, we make sure that pre- and post-event windows do not include previous or following intervention events in order to filter out the cumulative effect of actual interventions.

The results indicate that the inclusion of verbal interventions and interest news does not help improve the effectiveness of actual interventions in Romania, where success could not be established for any of the event definitions and pre- and post-event window sizes.

The results show some improvement for Croatia (compared to the net effect of actual interventions), as leaning-against-the-wind strategies are detected in a fairly robust manner for the 5-day window and, to a lesser extent, for the 10-day window in the period from 2001 to 2006.

The effectiveness of FX interventions improves remarkably in the Czech Republic and Slovakia. One reason for this is that, compared with net actual interventions, longer-term pre- and postevent windows were assessed, because the restriction due to overlaps with verbal interventions and interest news was lifted. For the Czech Republic, leaning-against-the-wind strategies can be observed at a 2-day horizon, which turn into very robust exchange rate smoothing beyond 30 days. In the same way, longer-term strong effects of FX interventions were identified for Slovakia, as actual interventions managed to reverse the exchange rate trend at the 10- to 30-day horizons.

For Turkey, actual discretionary interventions combined with verbal interventions and interest rate news turn out to be very effective, with significant exchange rate smoothing being observed for the 5-day window and with very robust leaning against the wind detected for the 40- and 50day pre- and post-event windows, irrespective of the definition of the intervention event. At the 
same time, the combination of discretionary and FX auction-based interventions yields leaningagainst-the-wind outcomes for the 10-day window and provides us with some suggestive evidence for exchange rate smoothing at the longer end of the spectrum.

The single intervention event observed in Hungary was highly effective in turning the appreciation of the exchange rate into a depreciation at all horizons investigated.

In general, actual interventions combined with central bank communication and news on interest rate policy are more powerful in affecting the exchange rate in such a way as defined by our success criteria. First, the results are less sensitive to different event window definitions. Second, and perhaps more importantly, the results indicate a longer lasting (up to 60 days) effect of actual interventions on the exchange rate.

A straightforward explanation for the dramatic increase in effectiveness is that, as shown in Figure 2, actual interventions are clustered with verbal interventions and interest rate steps. From a technical viewpoint, this implies that pre- and post-event windows cannot be assessed at longer time horizons without overlapping between the three factors. However, an increase in the number of assessable windows should not per se lead to better results. The reason why the rate of success and thus the statistical impact of FX interventions on the exchange rate - rises is that, if actual and verbal interventions and interest rate steps are clustered, they will often go in the same direction, i.e. they either support or weaken the domestic currency. It is precisely this mutual backing of the three factors which is most probably at the heart of the enhanced effectiveness.

\subsection{Combined Effect: Does Direction Matter?}

Disentangling the effects of domestic currency sales and purchases confirms our earlier results on the ineffectiveness of FX interventions in Romania and shows that in the Czech Republic and Turkey, the results obtained for actual interventions supported by central bank communication and interest rate news reflect the effect of domestic currency sales aimed at slowing down or reversing nominal appreciation. However, this approach reveals a more nuanced picture. In the Czech Republic, domestic currency sales appear to be even more successful than indicated by the aggre- 
gated data. In Turkey, discretionary interventions become slightly weaker in the longer run, while the combination of discretionary and auction-based interventions is a little more successful at the 2- and 5-day pre- and post-event windows. No changes are observed for Hungary, given that the single intervention event relates to domestic currency sales.

Disaggregation delivers more insight regarding the nature of success in Croatia and Slovakia. These are the two countries in which actual interventions in both directions are found to be effective. For Croatia, this is, however, true only for the period running from 2001 to 2006: Actual interventions were capable of reversing the trend of the exchange rate in both directions. In Slovakia, koruna sales tended to smooth the exchange rate at the 30-day horizon, while koruna purchases were even able to break a depreciation trend up to 60 days. Interestingly, however, disaggregating the results into currency sales and purchases in Croatia and Slovakia (contrary to the other countries) induces some sensitivity with regard to different event definitions.

\subsection{Cumulative Effect of Actual Interventions}

The final stage of our analysis consists of taking into account the effects of overlapping intervention events in the evaluation of the pre- and post-event windows. In other words, the windows are not adjusted for previous and following intervention events. In this way, the cumulative effect of previous and following FX interventions is also measured for any given intervention event, thus adding to the effect of the already included verbal interventions and interest rate news.

This does not only increase the number of assessable windows at longer time horizons, but apparently also raises the effectiveness of FX interventions via domestic currency sales. For instance, in Romania, actual interventions - thus far completely unsuccessful - show signs of moderate success in smoothing exchange rate appreciation. This is because intervention data are a mixture of daily and monthly data. This leads to frequent overlaps between intervention events and the exclusion of such overlapping events. By contrast, the cumulative effect allows the assessment of such overlapping events.

Furthermore, the cumulative effect of actual interventions is positive for Croatia and Slovakia 
when the central bank aims at slowing down depreciation or even reversing the trend. Defending the national currency against depreciation seems to be statistically significant also in the Czech Republic and Turkey. Nonetheless, the combined effect of discretionary and auction-based interventions vanishes for Turkey. 
Table 5. Summary of the results

\begin{tabular}{|c|c|c|c|c|c|c|c|c|}
\hline & HR-1 & HR-2 & $\mathrm{CZ}$ & $\mathrm{HU}$ & $\mathrm{RO}$ & $\mathrm{SK}$ & TK-1 & TK-2 \\
\hline \multicolumn{9}{|c|}{ Net effect of FX interventions central bank communication and interest news } \\
\hline FX int: Overall & W30? & $\mathrm{S} / \mathrm{W} 10$ & W2? & - & NO & S1? W5?,10 & NO & $\mathrm{NO}$ \\
\hline FX int: Weaken & $\mathrm{W} 2,10$ & W2?,10 & $\mathrm{W} 1,2$ & - & NO & $\mathrm{S} 1 ?, 5 \mathrm{~W} 2$ & W2 & NO \\
\hline FX int: Strengthen & NO & NO & NO & NO & NO & W1?,5 & NO & NO \\
\hline Verbal int: Overall & NO & NO & NO & NO & NO & NO & NO & NO \\
\hline Verbal int: Weaken & NO & NO & NO & S1 & NO & NO & NO & NO \\
\hline Verbal int: Strengthen & NO & NO & NO & NO & NO & NO & NO & NO \\
\hline Interest News: Overall & NO & NO & S20? & $\mathrm{S} 30$ & NO & NO & NO & NO \\
\hline Interest News: Weaken & NO & NO & S20? & $\mathrm{S} 30$ & NO & NO & NO & NO \\
\hline Interest News: Strengthen & NO & NO & NO & NO & NO & NO & NO & NO \\
\hline \multicolumn{9}{|c|}{ Combined effect of FX interventions, central bank communication and interest news } \\
\hline \multicolumn{9}{|c|}{ Excluding overlaps between FX intervention events } \\
\hline Overall & S5?,10? & $\mathrm{W} 5, \mathrm{~S} / \mathrm{W} 10$ & $\begin{array}{l}\text { W2 } \\
\text { S10?,30-60 }\end{array}$ & W1-60 & NO & W10-30 & $\begin{array}{l}\text { S5 W30? } \\
\text { W40,50 }\end{array}$ & $\begin{array}{l}\text { W10 } \\
\text { S 15-40? }\end{array}$ \\
\hline Weaken & W2? & W5?,10 & $\begin{array}{l}\text { W2, } 20 \\
\text { S10?15? } \\
\text { S30-60 }\end{array}$ & W1-60 & NO & $\begin{array}{l}\text { W2, 20? } \\
\text { W30?S1? } \\
\text { S5,15?40? }\end{array}$ & $\begin{array}{l}\text { W2,40? } \\
\text { W50? }\end{array}$ & S15-40? \\
\hline Strengthen & NO & W5-40? & NO & - & NO & $\begin{array}{l}\text { W5-15 } \\
\text { W30-60? }\end{array}$ & NO & NO \\
\hline & & ding ov & laps betw & n FX & nterven & on events & & \\
\hline Overall & NO & $\begin{array}{l}\text { S5,10? } \\
\text { S15,20 }\end{array}$ & S30?40-60 & - & NO & $\begin{array}{l}\text { W10? } \\
\text { S15,60 }\end{array}$ & $\begin{array}{l}\text { S0,5? } \\
\text { W } 30 ?\end{array}$ & W 5-15? \\
\hline Weaken & NO & $\begin{array}{l}\text { W2?5?10 } \\
\text { S20 }\end{array}$ & $\begin{array}{l}\text { W2,10,30? } \\
\text { W40? } \\
\text { W50,60 }\end{array}$ & - & $\begin{array}{l}\text { S0,20? } \\
30 ? 60 ?\end{array}$ & $\begin{array}{l}\text { S40?50 } \\
\text { S60 W2? }\end{array}$ & W20 & NO \\
\hline Strengthen & NO & W10-60? & W5-10 & - & NO & $\begin{array}{l}\text { W5,10 } \\
\text { W15?20 } \\
3050 ? 60\end{array}$ & $\begin{array}{l}\text { S0,10 } \\
\text { W2,20? }\end{array}$ & W2-30 \\
\hline
\end{tabular}

Notes: HR-1 refers to the whole period and HR-2 to the period from 2001 to 2006 in Croatia. CZ, HU, RO and SK denote the Czech Republic, Hungary,

Romania and Slovakia. TK-1 and TK-2 represent discretionary interventions and the combination of discretionary and auction-based interventions in Turkey. Overall stands for aggregate data, while weaken and strengthen denote the respective effect of interventions on the domestic currency. S stands for exchange rate smoothing, and $\mathrm{W}$ represents against-the-wind outcomes. The figures after S or W denote the pre-and post-event window size for which the nonparametric sign tests are significant for all event definitions. ? indicates that the results are only significant for three or four out of five possible (2-, 5-, 10-, 20- and 30-day) event definitions. 


\subsection{Impact of FX Interventions on FX Volatility}

Two out of the six central banks under study explicitly state in their official policy that they will intervene on the FX market in order to decrease excessive FX volatility. For this reason, we also use the event study approach to analyze whether there is a systematic increase or decrease in FX volatility, measured in terms of standard deviation, in the aftermath of central bank intervention. ${ }^{22}$

For Turkey, where the FX volatility target is a most prominent feature, we find that the net effects of discretionary FX interventions indeed decreased FX volatility systematically in the event that the central bank sold Turkish lira to counteract currency appreciation. However, this effect evaporates when we take into account the effect of central bank communication, interest rate news and possible overlaps between actual intervention events. Interventions that also include auctionbased interventions have no impact on exchange rate volatility if considered alone, but they result in lower FX volatility once the other factors are included. For Slovakia, the second country with the official objective to decrease FX volatility, we detected neither a positive nor a negative influence on FX volatility when we use data disaggregated into purchases and sales. Still, FX volatility seemed to rise as a result of FX interventions for the 10-day pre- and post-event windows.

Changes in exchange rate volatility owing to FX interventions can be viewed as a side effect of intervention activity aimed at influencing the level of the exchange rate. For Croatia, net FX interventions tend to increase FX volatility for the 5- to 15-day pre- and post-event windows, in particular when the central bank tries to counteract appreciation pressures. While volatility decreased at the short 5-day horizon after FX interventions, it increased (just like in Croatia) for the 10- to 15-day window when the Czech National Bank sold domestic currency. In Romania, central bank interventions turn out to be neutral to the variability of the exchange rate, while in Hungary, exchange rate volatility decreased after the single intervention episode.

22 The results are not reported here in order to save space. However, they are available from the author upon request. 


\subsection{Comparison with the Existing Literature}

How do our results compare with those reported in the literature? As noted earlier, Turkey and the Czech Republic have so far been covered extensively in the literature, and most of the studies use econometric estimations. For Turkey, Domac and Mendoza (2004) find that, on the basis of EGARCH estimations, only lira purchases have an influence on the exchange rate vis-à-vis the dollar from February 2001 to May 2002. Lira purchases indeed strengthened the exchange rate and decrease exchange rate volatility. The estimations carried out by Guimaraes and Karacadag (2004) for a two-year period running from March 2001 to October 2003 based on the component GARCH model yielded fairly different results, as central bank interventions did not affect the level of the exchange rate. In addition, only lira purchases impacted on exchange rate volatility: it decreased in the short run, but increased in the long run as a result of interventions. Using a very similar period (March 2001 to May 2003), Akinci et al. (2005a) show that lira sales led to a depreciation of the exchange especially in 2003. This is broadly confirmed by the event study approach. In a companion paper, Akinci et al. (2005b) show that interventions will be ineffective, if the estimations are based on a simple GARCH model. However, the estimation results also indicate that large and isolated interventions tend to decrease exchange rate volatility, whereas other types of intervention (small and auction-based ones) usually raise volatility.

Our results, based on a substantially longer period (2001-2006), indicate that discretionary lira sales are associated with a depreciation of the domestic currency in the short run. This supports the finding of Akinci et al. (2005a). However, when we also consider the effect of central bank communication and interest rate news, discretionary lira sales appear to have a longer-term (up to 60 day) mostly leaning-against-the-wind type of impact on the lira. Regarding exchange rate volatility, we find that only discretionary lira sales diminish exchange rate volatility and that this effect vanishes once verbal communication and interest rate news are properly accounted for.

For the Czech Republic, the instrumental variable approach reported in Disyatat and Galati (2005) yields a weakly significant influence on the exchange rate in the Czech Republic between 
2001 and 2002, while Égert and Komárek (2006) and Geršl and Holub (2006) report statistically significant but quantitatively not very large effects of interventions on the exchange rate using GARCH models for the period 1997 to 2002 and instrumental variable estimation for 2001 to 2003, respectively. Scalia (2006) establishes a quantitatively much stronger effect for intraday exchange rate data from July to September 2002.

Applying the event study approach to monthly data, Geršl and Holub (2006) find that interventions are successful in changing the exchange rate. However, they do not test the statistical significance of the pooled events. Égert and Komárek (2006) employ the sign bias test and shed light on the fact that actual interventions are only effective if combined with interest rate steps up to 40 days. Our results add more color to the picture in that they illustrate that koruna sales can reverse an appreciation trend on their own, albeit only in the very short run, and that combining interventions with central bank communication and interest rate news is very powerful in altering the trend of the exchange rate even up to 60 days. This suggests that appropriate central bank communication can enhance the effects of actual interventions and interest rate news.

Finally, Gereben, Gyomai and Kiss (2006) estimate the effectiveness of central bank interventions in Hungary by incorporating interventions in an order flow model of the exchange rate. The results indicate that interventions were successful only during the January 2003 crisis period, but not afterwards. The first result is in line with our results, which, however, are conditional on the effects of interest rate news and central bank communication. We argue that FX interventions after the January crisis were limited to selling off the reserves accumulated during the crisis, and to FX purchases for the government for servicing FX-denominated public debt. Consequently, the presence of the central bank on the FX market was not intended to influence the exchange rate. Nevertheless, Gereben, Gyomai and Kiss (2006) consider FX sales and purchases as proper central bank interventions after January 2003 and reveal their ineffectiveness, which - in our view only confirms that the central bank had no intention of influencing the exchange rate with these measures. 


\subsection{Sterilized vs. Unsterilized Interventions}

It is worth analyzing our results from a perspective of sterilization. We showed earlier that FX interventions are not fully sterilized in Croatia, while they are most probably sterilized in the other countries. Our results indicate that FX interventions have an effect on the exchange rate in Croatia. Yet this effect is not stronger than, for instance, in the Czech Republic or Slovakia, where interventions are sterilized.

The argument that unsterilized interventions automatically lead to changes in the exchange rate relies on the empirical validity of the monetary model of the exchange rate. The monetary model, in turn, rests on two assumptions, namely that (1) changes in money supply are reflected in prices via a stable money demand function, (2) which affects the nominal exchange rate through the purchasing power parity condition that links prices and the nominal exchange rate (existence of PPP for the real exchange rate). However, both assumptions rest on shaky grounds: First, money demand functions are notoriously unstable in transition economies, and second, PPP fails not only for the overall real exchange rate but also for the real exchange rate of the open sector (which is crucial for establishing the relationship between the exchange rate and money demand), as documented e.g. in Égert, Halpern and MacDonald (2006).

Despite these difficulties, Crespo-Cuaresma, Fidrmuc and MacDonald (2005), using panel data, show that the monetary model works fairly well for transition economies. However, CrespoCuaresma, Fidrmuc and Silgoner (2005) analyze the monetary model for individual countries and find that, while the monetary model is well suited to track down exchange rate movements in Romania and Turkey, it is unable to explain exchange rate developments in Bulgaria and Croatia. This outcome implies that, even though FX interventions are not necessarily fully sterilized in Croatia, their impact on the exchange rate is not proportionate because of the failure of the monetary model..$^{23}$

23 An additional complication is that the monetary model is validated using some long-term coefficients (cointegration techniques). This says little about how good the monetary model is at higher frequencies. 


\section{Conclusions}

In this study, we investigated the effectiveness of FX interventions in six emerging European countries employing the event study methodology. We found that central bank interventions adjusted for other factors were successful in slowing down or reversing an exchange rate trend in the short run, i.e. up to 10 days, in Croatia, the Czech Republic, Slovakia and Turkey. Short-term success was most pronounced when interventions aimed to ease appreciation pressures. At the same time, interventions were found to be ineffective in Romania and not assessable at all in Hungary because interventions overlapped with other factors. Using the event study methodology, it is difficult to establish which channel interventions affect the exchange rate. Three channels may play a role in Croatia, where interventions are announced in advance: the signaling channel, the portfolio channel as well as the microstructure (order-flow) channel. However, for the other countries with secret discretionary interventions, we assume that only the portfolio and the microstructure channels transmit the effect of interventions to the exchange rate.

While the sign bias test reveals very short-term effects of central bank communication only for Hungary and longer-term influence of interest news only for the Czech Republic and Hungary, interventions coupled with central bank communication and backed by interest rate moves turn out to have a longer lasting effect on the exchange rate for all countries. This holds especially true for domestic currency sales. In addition, if different intervention events are allowed to amplify each other's effect, even domestic currency purchases turn out to cope successfully with a depreciation of the domestic currency in Croatia, the Czech Republic, Slovakia and Turkey.

However, the observed outcome can be viewed as a real success only, if it is in line with the officially stated objectives of central bank interventions. As a matter of fact, the observed effect of interventions on the exchange rate is generally compatible with the central banks' objectives relating to changes in the exchange rate in Croatia, the Czech Republic and, to a lesser extent, in Romania and with the objective of maintaining the fluctuation bands in Hungary. 
This, however, cannot be fully said for Slovakia and Turkey based on the results of the event study analysis for the period from 1999 to 2006 and from 2001 to 2006, respectively. Although the National Bank of Slovakia successfully counteracts what it calls excessive depreciation and appreciation pressures, the goal of reducing exchange rate volatility has apparently remained unfulfilled. The central bank of Turkey does not achieve the single aim of systematically reducing exchange rate volatility via discretionary interventions with a combination of verbal interventions and interest rate news. Moreover, a side-effect of discretionary and also of auction-based interventions is their significant impact on the exchange rate.

We also looked into the issue of sterilization and found that most central banks, perhaps with the exception of Croatia, tended to fully sterilize FX interventions. Interestingly, this partial sterilization in Croatia does not lead to a substantial improvement of the effectiveness of FX interventions as compared to the other countries - the monetary model, which ensures that unsterilized interventions are transmitted to the exchange rate, is not operational in Croatia (see Crespo-Cuaresma, Fidrmuc and Silgoner, 2005). This makes us cautious about the generally accepted view that unsterilized interventions automatically influence the exchange rate.

\section{References}

Akinci, Özge, Olcay Yücel Çulha, Ümit Özlale and Gülbin Şahinbeyoğlu, 2005a. The effectiveness of foreign exchange interventions for the Turkish economy: A post-crisis period analysis, Central Bank of the Republic of Turkey Research Departement Working Paper No. 06. CBRT, Ankara.

Akinci, Özge, Olcay Yücel Çulha, Ümit Özlale and Gülbin Şahinbeyoğlu, 2005b. Causes and effectiveness of foreign exchange interventions for the Turkish economy, Central Bank of the Republic of Turkey Research Departement Working Paper No. 05. CBRT, Ankara

Bindseil, Ulrich, 2002. Central bank forecasts of liquidity factors and the control of short term interest rates. Banca-Nazionale-del-Lavoro-Quarterly-Review 55 (220), 13-37 and European Cen- 
tral Bank Working Paper No. 70. ECB, Frankfurt

Canales-Kriljenko, Jorge Iván, 2003. Foreign exchange intervention in developing and transition economies: Results of a survey. International Monetary Fund Working Paper No. 95. IMF, Washington, DC.

Central Bank of the Republic of Turkey, 2001, 2002, 2003, 2004. Annual Report. Ankara

Chmelarova, Viera, Schnabl, Gunther, 2006. Exchange rate stabilization in developed and underdeveloped capital markets. European Central Bank Working Paper No. 636. ECB, Frankfurt.

Coats, Warren, 2000. Inflation Targeting in Transition Economies: The Case of the Czech Republic. Czech National Bank, Prague and International Monetary Fund,Washington.

Available at http://www.cnb.cz/pdf/mmf-final.pdf.

Crespo-Cuaresma, Jesús, Fidrmuc, Jarko, MacDonald, Ronald, 2005. The monetary approach to exchange rates in the CEECs. Economics of Transition 13, 395-416.

Crespo-Cuaresma, Jesús, Fidrmuc, Jarko, Silgoner, Maria-Antoinette, 2005. On the road: The path of Bulgaria, Croatia and Romania to the EU and the euro. Europe-Asia Studies 57, 843-858.

Croatian National Bank, 2001, 2003. Annual Report. Zagreb.

Czech National Bank, 1998, 1999, 2000, 2002. Annual Report. Prague.

Disyatat, Piti, Galati, Gabriele, 2005. The Effectiveness of foreign exchange intervention in emerging market countries: Evidence from the Czech koruna. Bank for International Settlement Working Papers No. 172. BIS, Basel.

Domaç, Ilker, Mendoza, Alfonso, 2004. Is there room for forex interventions under inflation targeting framework? Evidence from Mexico and Turkey. World Bank Policy Research Working Paper No. 3288. World Bank, Washington, DC.

Cashin, Paul, Edison, Hali J., Liang, Hong, 2006. Foreign exchange intervention and the Australian dollar: Has it mattered? International Journal of Finance \& Economics 11(2), 155-171.

Égert, Balázs, Halpern, László, MacDonald, Ronald, 2006. Equilibrium exchange rates in transition economies. Journal of Economic Survey 20(2), 257-324. 
Égert, Balázs, Komárek, Luboš, 2006. Foreign exchange interventions and interest rate policy in the Czech Republic: Hand in glove? Economic Systems 30(2), 121-140.

Érsek, Zsolt, 2005. Defending the strong side of the band - The Hungarian experience. Bank for International Settlements Papers No. 24, 171-176. BIS, Basel.

Fatum, Rasmus, 2002. On the effectiveness of sterilised foreign exchange intervention. Canadian Journal of Economics, 35(3), 556-567.

Fatum, Rasmus, 2005. Daily effects of foreign exchange intervention: Evidence from official Bank of Canada data. School of Business, University of Alberta, mimeo.

Fatum, Rasmus, Hutchison, Michael M. 2003. Is sterilised foreign exchange intervention effective after all? An event study approach. Economic Journal 113(487), 390-411.

Fratzscher, Marcel, 2005. How successful are exchange rate communication and interventions? Evidence from time series and event-study approaches. European Central Bank Working Paper No. 528. ECB, Frankfurt.

Gereben, Áron, Gyomai, György, Kiss, M. Norbert, 2006. Customer order flow, information and liquidity on the Hungarian foreign exchange market. Working Paper No. 8. National Bank of Hungary, Budapest.

Geršl, Adam, Holub, Tomáš, 2006. Foreign exchange interventions under inflation targeting: The Czech experience. Contemporary Economic Policy 24(4), 475-491.

Guimarães, Roberto, Karacadag, Cem, 2004. The empirics of foreign exchange intervention in emerging market countries: The case of Mexico and Turkey. International Monetary Fund Working Paper No. 123. IMF, Washington, DC.

Humpage, Owen F., 1999. U.S. Intervention: assessing the probability of success. Journal of Money, Credit and Banking 31(4), 731-747.

MacKinley, A. Craig, 1997. Event studies in economics and finance. Journal of Economic Literature 35(1), 13-39.

National Bank of Romania, 2005a. Monthly Bulletin, March. Bucharest. 
National Bank of Romania, 2005b. Monthly Bulletin, August. Bucharest.

National Bank of Romania, 2005c. Inflation Report, November. Bucharest.

National Bank of Slovakia, 1998, 2000, 2001, 2002, 2003, 2004. Annual Report. Bratislava.

Radulescu, Bogdan, 2004. Central bank interventions in the Romanian foreign exchange market: estimating a reaction function. Master Thesis. Academy of Economic Studies. Bucharest.

Sarno, Lucio, Taylor, Mark P., 2001. Official intervention in the foreign exchange market: Is it effective, and, if so, how does it work? Journal of Economic Literature 39(3), 839-868.

Scalia, Antonio, 2006. Is foreign exchange intervention effective? Some micro-analytical evidence from the Czech Republic. Temi di discussione No. 579. Banca d'Italia, Rom.

Šmídkova, Kateřina., Běhumek, Jiři, Hlédik, Tibor, Jílek, Josef, Koštel, Miroslav, Matalíková, Ivana, Rottová, Dana, Staňková, Jana, 1998. Koruna exchange rate turbulence in May 1997. Czech National Bank Working Paper No. 2. CNB, Prague.

\section{Appendix A. Monetary Framework and Institutional Background}

\section{A1. Monetary policy framework}

Croatia switched to a managed float in 1993 which is maintained up to now. In practice, however, the exchange rate of the kuna against the German mark and later on against the euro was maintained by means of frequent FX interventions in a narrow band of around $10 \%$ with the implicit fluctuation band being even narrower during some periods. The stability of the kuna bore fruit early on as hyperinflation was quickly tamed and inflation was stabilized in one-digit territory from 1995 onward (see Table A1).

The Czech Republic and Slovakia used fixed exchange rates successfully to bring down inflation from around $60 \%$ in 1991 - chiefly a consequence of price liberalization - to below $10 \%$ in 1995 . However, the Czech koruna came under increasing pressure on the FX market in the first half of 1997 because of long-delayed macroeconomic restructuring coupled with political turbulence and 
with the start of the Asian currency crisis in Thailand. The speculative attack, largely facilitated by extensive capital account liberalization, forced the Czech National Bank and the government to abandon the peg and announce the introduction of a managed float on May 26, 1997. Slovakia followed suit one year later, as FX reserves were declining at a rapid pace in the aftermath of the Russian crisis, and introduced a managed float on October 1, 1998. Under the float, both the Czech and the Slovak central banks kept an eye on the domestic currency's exchange rate vis-àvis the German mark and the euro and intervened periodically on the FX markets, even though the exchange rate anchor was replaced by the announced inflation target under the direct inflation targeting framework introduced in 1998 in the Czech Republic. The Czech Republic complied with Article VIII of the IMF from October 1, 1995, onward and joined the OECD in December 1995. FX interventions were motivated by the fear that large exchange rate fluctuations could possibly have painful consequences on the real economy because of the high degree of trade openness.

Hungary and Romania stuck to pegged regimes longer that the Czech Republic and Slovakia. After having operated a narrow pegged regime with frequent discretionary devaluations, Hungary adopted a pre-announced crawling peg regime with a band of $\pm 2.25 \%$ around the central parity in March 1995 as part of a stabilization program aimed at reducing internal and external imbalances. As a result of economic reforms, both foreign direct and portfolio investment started to flow in, which pushed the exchange rate to the stronger edge of the band. This forced the central bank to step in and sell domestic currency. In the crawling peg regime, the progressive reduction of the pre-announced rate of crawl (devaluation of the central parity) contributed to a gradual reduction of inflation. However, inflation got stuck at $10 \%$ in 2000 at a time when the rate of crawl was virtually zero. Against this backdrop, the fluctuations band was widened to $\pm 15 \%$ in May 2001 . The exchange rate appreciated immediately and gave new impetus to disinflation. Within the inflation targeting framework, which was introduced in June 2001, heavy weight has been given to the exchange rate. Indeed, the exchange rate has remained on the stronger side of the fluctuation band ever since. The main tools of stabilizing the exchange rate were interest rate policy and verbal 
interventions. Similar to the crawling peg system, the central bank intervenes only at the upper and lower edges of the band.

Table A1. Average annual CPI rates in transition economies and in Turkey, 1990-2004.

\begin{tabular}{lrrrrrrrrrrrrrrr}
\hline \hline \multicolumn{1}{c}{ \% } & \multicolumn{1}{c}{ '91 } & \multicolumn{1}{c}{ '92 } & \multicolumn{1}{c}{ '93 } & \multicolumn{1}{c}{ '94 } & \multicolumn{1}{c}{ '95 } & \multicolumn{1}{c}{ '96 } & \multicolumn{1}{c}{ '97 } & \multicolumn{1}{c}{ '98 } & \multicolumn{1}{c}{ '99 } & \multicolumn{1}{c}{ '00 } & '01 & '02 & '03 & '04 & '04 \\
\hline Croatia & 123.0 & 665.5 & 1517.5 & 97.6 & 2.0 & 3.5 & 3.6 & 5.7 & 4.2 & 6.2 & 4.9 & 1.7 & 1.8 & 2.1 & 3.4 \\
Czech Rep. & 56.6 & 11.1 & 20.8 & 10.0 & 9.1 & 8.8 & 8.5 & 10.7 & 2.1 & 3.9 & 4.7 & 1.8 & 0.1 & 2.8 & 1.9 \\
Hungary & 35.0 & 23.0 & 22.5 & 18.8 & 28.2 & 23.6 & 18.3 & 14.3 & 10.0 & 9.8 & 9.2 & 5.3 & 4.7 & 6.8 & 3.8 \\
Romania & 170.2 & 210.4 & 256.1 & 136.8 & 32.3 & 38.8 & 154.8 & 59.1 & 45.8 & 45.7 & 34.5 & 22.5 & 15.3 & 11.9 & 9.1 \\
Slovakia & 61.2 & 10.0 & 23.2 & 13.4 & 9.9 & 5.8 & 6.1 & 6.7 & 10.6 & 12.0 & 7.1 & 3.3 & 8.5 & 7.5 & 2.5 \\
Turkey & 66.0 & 70.1 & 66.1 & 106.3 & 88.1 & 80.4 & 85.7 & 84.6 & 64.9 & 54.9 & 54.4 & 45.0 & 25.3 & 8.6 & 8.2 \\
\hline \hline
\end{tabular}

Source: WIIW and IFS/IMF (Turkey)

Note: Inflation rates refer to the national CPIs and not to the harmonized consumer price indexes published by Eurostat.

Romania operated an implicit crawling band system, in which the exchange rate underwent gradual but systematic and sometimes large depreciations guided by FX interventions. As a result - and because of the lack of economic reforms and credible macroeconomic policies - inflation and inflationary expectations remained high during the 1990s (see Table A1). Economic restructuring has speeded up and economic policy has gained more credibility over the last five years or so. Accompanied by the liberalization of capital movements, this has attracted considerable foreign investment, which has made it more difficult to continue the tight management of the exchange rate. Consequently, the Romanian central bank decided to let the leu float in November 2004. This can be viewed as a preparatory step toward direct inflation targeting implemented in mid- 2005 . Note that the National Bank of Romania had an implicit inflation target since 1998 that has been laid down in Romania's Medium-Term Economic Strategy since 2001. The new exchange rate regime is a managed float and the central bank intervenes occasionally on the FX market.

Just like Romania, Turkey has a long-standing record of high inflation. The latest attempt of stabilization, which rested on a pre-announced crawling peg exchange rate regime culminated in a currency crisis in early 2001. As a result, a floating exchange rate regime was introduced in Turkey on February 22, 2001. This was part of a new monetary policy framework, which can be best described as implicit inflation targeting. Under this regime, the central bank pursues an 
inflation target at a given horizon in the future. The central bank's main instruments are shortterm interest rates. The base money and net international reserves are used as "indicative criteria", which can be perhaps deemed as intermediate targets. Net domestic assets, measuring domestic credit expansion, are considered as an indicator of the monetary policy stance. This monetary policy framework was underpinned with the amendment of the Central Bank Act on May 5, 2001, which aimed at securing the operational independence of the central bank. Notwithstanding the limited role of FX interventions in such a framework, the Central Bank of the Republic of Turkey intervened on a number of occasions on the FX markets between 2001 and early 2006.

\section{A2. Objectives of FX Interventions}

\section{Croatia}

HNB (2001, p. 33): "The kuna/euro value grew by $1.8 \%$ in nominal terms in July in comparison with end-June, while it had strengthened by $0.5 \%$ in July 2000 . In an effort to eases the intense appreciation of the exchange rate of the kuna against the euro, the central bank purchases from banks a total of USD $122.9 \mathrm{~m} . "$

HNB (2001, p. 34): “The last quarter of 2001 was marked by a nominal appreciation of the kuna against the euro of $2.3 \%(.$.$) . In an effort to keep exchange rate movements within satisfactory$ stability boundaries, the central bank purchased from banks a total of USD $338.5 \mathrm{~m} . ”$

HNB, 2003, p. 40): "In this period, the kuna weakened against the euro by a total of $3.4 \%$ (...). The kuna depreciation stimulated the sale of foreign exchange at the central bank's auctions in the first quarter of 2003."

\section{Czech Republic}

In the immediate aftermath of the speculative run against the koruna, the CNB strived to stabilize the exchange rate against the German mark and announced a target band of 17-19.5 CZK/DEM (33.5-38.5 CZK/EUR) (Šmídkova et al., 1998, pp. 10-11). 
Interventions were made in case of "major deviations of the exchange rate that are not connected with domestic economic fundamentals and domestic monetary policy" (CNB, 1998, p. 46).

CNB (1998, p 33.): "The CNB intervened on the foreign exchange market to moderate the appreciation pressures generated by the foreign capital inflow."

CNB (1999, p 45.): “the koruna's exchange rate was affected by the CNB's interventions to prevent an excessive koruna appreciation."

CNB (2000, p. 48): “The koruna's nominal exchange rate against the euro exhibited an overall appreciation tendency in 2000. This gradual strengthening was interrupted at end-Q1 by the CNB's foreign exchange interventions to prevent excessive appreciation of the koruna..."

CNB (2002, p. 36): "The koruna continued to appreciate (...). As a result, at its extraordinary meeting on 21 January 2002 the Bank Board (...) also approved intervention in the foreign exchange market."

\section{Romania}

NBR (2005b, p 7.): "The pressure causing the domestic currency to strengthen in nominal terms against the euro stepped up significantly. The central bank viewed this process as unsustainable and therefore bought large amounts of foreign currency in the foreign exchange market".

NBR (2005c, p. 33): "In an attempt to dampen volatile capital inflows and to put a halt to the excessive appreciation of the RON, in July-August, the central bank purchases a record high volume of foreign currency on the forex market".

NBR (2005a, p. 7): “... the central bank's intervention in the foreign exchange market, which was chiefly aimed at maintaining, as from March, a relatively steady level of foreign exchange reserves (in terms of import months)...".

\section{Slovakia}

NBS (2001, p. 65): "The National Bank of Slovakia may intervene in the interbank foreign exchange market in the event of excessive volatility in the exchange rate of the Slovak koruna". 
Very similar statements can be found in NBS (1998, p. 65), NBS (2000, p. 56) and NBS (2002, p. $56)$.

NBS (2002, p. 60): “This led to growing pressure for appreciation in the exchange rate of the Slovak koruna in the first half of November. This exchange rate development was caused mostly by non-economic and speculative factors, and was not in accordance with the actual course of economic development. For this reason, the NBS intervened in the foreign exchange market against appreciation of the currency..."

NBS (2003, p. 70): "The National Bank of Slovakia intervened in the foreign exchange market in the event of excessive volatility in the exchange rate of the Slovak koruna and/or if the exchange rate did not correspond to the indicators of macroeconomic developments." See also NBS (2004, p. 62).

\section{Turkey}

CBRT (2001, p. 109): “The Central Bank conducted regular FX sales auctions after March 29 in order to smooth excessive short-run exchange rate fluctuations without affecting the long-run equilibrium level of exchange rates..."

CBRT (2002, p. 71): “...the Central Bank announced that it would intervene in the foreign exchange rate market in a strictly limited fashion to prevent excessive volatility without targeting a certain trend level."

CBRT (2004, paragraph 34): "The Bank has not performed any foreign exchange buying or selling operations intended at determining the level or direction of the exchange rates. The Bank's foreign exchange buying or selling operations aimed at controlling excessive volatilities."

CBRT (2004, p. 73): “The CBRT (...) would hold foreign exchange purchase auctions in order to increase foreign exchange reserves without distorting the long-run tendency and equilibrium value of the exchange rate."

CBRT (2003, p.97): “(...) it would directly intervene in the event of excessive volatility that 
might occur in both directions." See also CBRT (2004, p. 73).

CBRT (2002, p. 96): “(...) the Central Bank did not target any exchange rate level and that it would respond symmetrically to both upward and downward volatility." 


\section{Appendix B. Results}

\section{Table B1. Actual interventions adjusted for verbal interventions and interest news NONPARAMETRIC SIGN TEST - p-values}

\begin{tabular}{|c|c|c|c|c|c|c|c|c|c|c|c|c|}
\hline \multirow{2}{*}{ EVENT SIZE } & & \multicolumn{11}{|c|}{ PRE- AND POST-EVENT WINDOW } \\
\hline & & $\mathrm{W}$ & 1 & 2 & 5 & 10 & 15 & 20 & 30 & 40 & 50 & 60 \\
\hline & & \multicolumn{11}{|c|}{ Croatia 1996 - 2006} \\
\hline \multirow[t]{2}{*}{2 DAYS } & wind & 0.997 & 1.000 & 1.000 & 0.964 & 0.277 & 0.500 & 0.287 & 0.250 & & & \\
\hline & smooth & 0.978 & 1.000 & 1.000 & 0.138 & 0.087 & 0.066 & 0.500 & 0.750 & & & \\
\hline \multirow[t]{2}{*}{5 DAYS } & wind & 0.805 & 1.000 & 0.994 & 0.962 & 0.188 & 0.238 & 0.301 & 0.146 & 0.250 & 0.250 & \\
\hline & smooth & 1.000 & 1.000 & 1.000 & 0.095 & 0.188 & 0.238 & 0.301 & 0.854 & 0.102 & 0.102 & \\
\hline \multirow[t]{2}{*}{10 DAYS } & wind & 0.884 & 1.000 & 0.962 & 0.446 & 0.249 & 0.410 & 0.500 & 0.091 & 0.250 & 0.250 & \\
\hline & smooth & 1.000 & 1.000 & 1.000 & 0.554 & 0.155 & 0.410 & 0.500 & 0.909 & 0.102 & 0.102 & \\
\hline \multirow[t]{2}{*}{20 DAYS } & wind & 0.937 & 1.000 & 0.967 & 0.500 & 0.107 & 0.406 & 0.406 & 0.187 & $\overline{0.500}$ & $\overline{0.500}$ & \\
\hline & smooth & 1.000 & 1.000 & 1.000 & 0.735 & $\overline{0.663}$ & 0.594 & 0.594 & 0.942 & 0.146 & 0.146 & \\
\hline \multirow[t]{3}{*}{30 DAYS } & wind & 0.852 & 1.000 & 0.952 & 0.500 & 0.077 & 0.384 & 0.384 & 0.077 & 0.500 & 0.500 & \\
\hline & smooth & 1.000 & 0.999 & 1.000 & 0.633 & 0.969 & 0.971 & 0.971 & 0.975 & 0.146 & 0.146 & \\
\hline & & \multicolumn{11}{|c|}{ Croatia $2001-2006$} \\
\hline \multirow[t]{2}{*}{2 DAYS } & wind & 0.881 & 1.000 & 0.864 & 0.500 & 0.250 & 0.384 & 0.271 & & & & \\
\hline & smooth & 0.962 & 0.997 & 1.000 & 0.500 & 0.004 & 0.080 & 0.271 & & & & \\
\hline \multirow[t]{2}{*}{5 DAYS } & wind & 0.616 & 1.000 & 0.888 & 0.208 & 0.154 & 0.152 & 0.287 & 0.250 & & & \\
\hline & smooth & 0.997 & 0.986 & 1.000 & 0.565 & 0.006 & 0.301 & 0.135 & 0.750 & & & \\
\hline \multirow[t]{2}{*}{10 DAYS } & wind & 0.607 & 0.999 & 0.792 & 0.043 & 0.211 & 0.312 & 0.500 & 0.146 & & & \\
\hline & smooth & 0.998 & 1.000 & 1.000 & 0.500 & 0.002 & 0.500 & 0.301 & 0.854 & & & \\
\hline \multirow[t]{2}{*}{20 DAYS } & wind & 0.699 & 0.998 & 0.765 & 0.163 & 0.054 & 0.301 & 0.301 & 0.146 & & & \\
\hline & smooth & 0.999 & 1.000 & 1.000 & 0.578 & 0.238 & 0.699 & 0.301 & 0.854 & & & \\
\hline 30 DAYS & wind & 0.393 & 0.992 & 0.657 & 0.133 & 0.029 & 0.250 & 0.250 & 0.058 & & & \\
\hline & smooth & 0.998 & 0.999 & 1.000 & 0.410 & 0.807 & 0.989 & 0.902 & 0.942 & & & \\
\hline & & & & & & Czech & Repu & iblic & & & & \\
\hline 2 DAYS & wind & 0.920 & 0.108 & 0.172 & 0.881 & 0.302 & 0.302 & 0.500 & & & & \\
\hline & smooth & 0.807 & $\overline{0.999}$ & 0.993 & 0.119 & 0.302 & 0.302 & 0.146 & & & & \\
\hline 5 DAYS & wind & 0.957 & 0.210 & 0.147 & 0.813 & 0.302 & 0.302 & 0.500 & & & & \\
\hline & smooth & 0.729 & 0.998 & 0.983 & 0.500 & 0.302 & 0.302 & 0.146 & & & & \\
\hline 10 DAYS & wind & 0.935 & 0.135 & 0.077 & 0.813 & 0.302 & 0.302 & 0.500 & & & & \\
\hline & smooth & 0.627 & 0.998 & 0.975 & 0.500 & 0.302 & 0.302 & 0.146 & & & & \\
\hline 20/30 DAYS & wind & 0.853 & 0.135 & 0.077 & 0.813 & 0.302 & 0.302 & 0.500 & & & & \\
\hline & smooth & 0.358 & 0.998 & 0.975 & 0.500 & 0.302 & 0.302 & 0.146 & & & & \\
\hline & & & & & & & angary & & & & & \\
\hline The single event & & -- & -- & -- & -- & -- & -- & -- & -- & -- & -- & -- \\
\hline & & & & & & & mania & & & & & \\
\hline 2/5/10 DAYS & wind & 0.750 & 0.698 & 0.146 & 0.750 & & & & & & & \\
\hline & smooth & 0.750 & 0.909 & 0.854 & 0.102 & & & & & & & \\
\hline 20/30 DAYS & wind & 0.750 & 0.500 & 0.250 & & & & & & & & \\
\hline & smooth & 0.750 & 0.854 & 0.750 & & & & & & & & \\
\hline & & & & & & & ovakia & & & & & \\
\hline 2 DAYS & wind & 0.607 & 0.500 & 0.600 & 0.271 & 0.053 & & & & & & \\
\hline & smooth & 0.987 & 0.834 & 0.999 & 0.271 & 0.854 & & & & & & \\
\hline 5 DAYS & wind & 0.848 & 0.713 & 0.384 & 0.172 & 0.053 & & & & & & \\
\hline & smooth & 0.699 & 0.020 & 0.997 & 0.172 & 0.854 & & & & & & \\
\hline 10 DAYS & wind & 0.906 & 0.500 & 0.373 & 0.050 & 0.032 & 0.102 & 0.102 & & & & \\
\hline & smooth & 0.607 & 0.043 & 0.993 & 0.358 & 0.909 & 0.750 & 0.750 & & & & \\
\hline 20/30 DAYS & wind & 0.807 & 0.147 & 0.777 & 0.058 & 0.053 & $\underline{0.102}$ & $\underline{0.102}$ & & & & \\
\hline & smooth & 0.807 & 0.983 & 0.975 & 0.500 & 0.854 & 0.750 & 0.750 & & & & \\
\hline & & & & Tur & key - & Discret & tionary & $\mathrm{y}$ interv & ventio & & & \\
\hline 2 DAYS & & & 0.688 & 0.225 & 0.883 & 0.302 & & & & & & \\
\hline & smooth & & 0.969 & 0.999 & 0.005 & 0.302 & & & & & & \\
\hline 5/10/20/30 DAYS & wind & & 0.600 & 0.301 & 0.828 & 0.302 & & & & & & \\
\hline & smooth & & 0.994 & 0.999 & 0.022 & 0.302 & & & & & & \\
\hline & & & Turke & $y-D i$ & scretic & onary \& & aucti & ion-bas & sed int & terventi & ions & \\
\hline 2 DAYS & wind & & 0.688 & 0.225 & 0.883 & 0.302 & & & & & & \\
\hline 2 DAYS & wind & 0.358 & 0.250 & 0.950 & 0.698 & 0.102 & & & & & & \\
\hline & smooth & 0.983 & 0.989 & 0.983 & 0.032 & $\overline{0.750}$ & & & & & & \\
\hline $5 / 10 / 20 / 30$ DAYS & wind & 0.302 & 0.187 & 0.698 & 0.698 & 0.102 & & & & & & \\
\hline & smooth & 0.909 & 0.942 & 0.909 & 0.032 & 0.750 & & & & & & \\
\hline
\end{tabular}

Notes: wind indicates leaning against the wind and smooth means exchange rate smoothing. Empty cells indicate that there are no assessable preand post-event windows because of overlaps or no successful events. The column pre- and post-event window indicates the size of the windows. $\mathrm{W}$ indicates that a pre-event window of 2 days is compared with exchange rate development within the event window. The event size columns contain the alternative definitions of the event window (how many days of no intervention activity separating two individual intervention acts belonging to the same event). Bold figures are lower than 0.1 , indicating that the nonparametric sign test is statistically significant at least at the $10 \%$ level 
Table B2. Actual interventions: direction matters NONPARAMETRIC SIGN TEST - p-values

\begin{tabular}{|c|c|c|c|c|c|c|c|c|c|c|c|c|}
\hline \multirow[b]{2}{*}{ EVENT SIZE } & & \multicolumn{11}{|c|}{ PRE- AND POST-EVENT WINDOW } \\
\hline & & $\mathrm{W}$ & 1 & 2 & 5 & 10 & 15 & 20 & 30 & 40 & 50 & 60 \\
\hline \multicolumn{13}{|c|}{ DIRECTION: EXCHANGE RATE STRENGTHENING } \\
\hline & & & & & & & ovakia & & & & & \\
\hline \multirow[t]{2}{*}{2 DAYS } & wind & 0.500 & 0.223 & 0.975 & 0.119 & 0.102 & & & & & & \\
\hline & smooth & 0.500 & 0.500 & 0.500 & 0.500 & 0.500 & & & & & & \\
\hline \multirow[t]{2}{*}{5 DAYS } & wind & 0.500 & 0.119 & 0.962 & 0.058 & 0.102 & & & & & & \\
\hline & smooth & 0.500 & 0.500 & 0.500 & 0.500 & 0.500 & & & & & & \\
\hline \multirow[t]{2}{*}{10 DAYS } & wind & 0.500 & 0.058 & 0.942 & 0.032 & 0.053 & 0.102 & 0.102 & & & & \\
\hline & smooth & 0.500 & 0.500 & 0.500 & 0.500 & 0.500 & 0.500 & 0.500 & & & & \\
\hline \multirow[t]{2}{*}{ 20/30 DAYS } & wind & 0.500 & 0.058 & 0.942 & 0.032 & 0.053 & 0.102 & 0.102 & & & & \\
\hline & smooth & 0.500 & 0.500 & 0.500 & 0.500 & 0.500 & 0.500 & 0.500 & & & & \\
\hline \multicolumn{13}{|c|}{ DIRECTION: EXCHANGE RATE WEAKENING } \\
\hline & & & & & & Croatia & 1996 & 2006 & & & & \\
\hline \multirow[t]{2}{*}{2 DAYS } & wind & 0.993 & 1.000 & 0.025 & 0.832 & 0.054 & 0.271 & 0.271 & 0.250 & & & \\
\hline & smooth & 0.935 & 1.000 & 1.000 & 0.943 & 0.594 & 0.271 & 0.729 & 0.750 & & & \\
\hline \multirow[t]{2}{*}{5 DAYS } & wind & 0.500 & 1.000 & 0.065 & 0.679 & 0.022 & 0.094 & 0.287 & 0.146 & 0.250 & 0.250 & \\
\hline & smooth & 0.996 & 0.999 & 1.000 & 0.562 & 0.663 & 0.607 & 0.500 & 0.854 & 0.102 & 0.102 & \\
\hline \multirow[t]{2}{*}{10 DAYS } & wind & 0.678 & 1.000 & 0.050 & 0.249 & 0.042 & 0.225 & 0.500 & 0.091 & 0.250 & 0.250 & \\
\hline & smooth & 0.998 & 1.000 & 1.000 & 0.633 & 0.578 & 0.775 & 0.699 & 0.909 & 0.102 & 0.102 & \\
\hline 20 DAYS & wind & 0.834 & 1.000 & 0.122 & 0.349 & 0.087 & 0.400 & 0.400 & 0.187 & 0.500 & 0.500 & \\
\hline & smooth & 0.996 & 0.992 & 1.000 & 0.875 & 0.678 & 0.775 & 0.775 & 0.942 & 0.146 & 0.146 & \\
\hline 30 DAYS & wind & 0.699 & 1.000 & 0.077 & 0.415 & 0.094 & 0.500 & 0.500 & 0.119 & 0.500 & 0.500 & \\
\hline & smooth & 0.991 & 0.964 & 1.000 & 0.585 & 0.906 & 0.957 & 0.957 & 0.962 & 0.146 & 0.146 & \\
\hline & & & & & & roatia & $2001-$ & 2006 & & & & \\
\hline 2 DAYS & wind & 0.942 & 1.000 & 0.129 & 0.657 & 0.094 & 0.250 & 0.250 & & & & \\
\hline & smooth & 0.942 & 0.997 & 1.000 & 0.942 & 0.210 & 0.500 & 0.500 & & & & \\
\hline 5 DAYS & wind & 0.627 & 1.000 & 0.180 & 0.277 & 0.054 & 0.080 & 0.271 & 0.250 & & & \\
\hline & smooth & 0.993 & 0.992 & 1.000 & 0.958 & 0.238 & 0.807 & 0.271 & 0.750 & & & \\
\hline 10 DAYS & wind & 0.729 & 0.995 & 0.087 & 0.071 & 0.087 & 0.210 & 0.500 & 0.146 & & & \\
\hline & smooth & 0.995 & 0.999 & 1.000 & 0.856 & 0.087 & 0.906 & 0.500 & 0.854 & & & \\
\hline 20 DAYS & wind & 0.627 & 0.997 & 0.144 & 0.238 & 0.066 & 0.287 & 0.287 & 0.146 & & & \\
\hline & smooth & 0.993 & 0.997 & 1.000 & 0.879 & 0.301 & 0.865 & 0.500 & 0.854 & & & \\
\hline 30 DAYS & wind & 0.358 & 0.978 & 0.077 & 0.287 & 0.065 & 0.358 & 0.358 & 0.091 & & & \\
\hline & smooth & 0.983 & 0.978 & 0.999 & 0.500 & 0.627 & 0.983 & 0.853 & 0.909 & & & \\
\hline & & & & & & Czech & Repu & blic & & & & \\
\hline 2 DAYS & wind & 0.902 & 0.054 & 0.098 & 0.813 & 0.146 & 0.146 & 0.250 & & & & \\
\hline & smooth & 0.902 & 0.998 & 0.989 & 0.058 & 0.146 & 0.146 & 0.102 & & & & \\
\hline 5 DAYS & wind & 0.950 & 0.117 & 0.077 & 0.698 & 0.146 & 0.146 & 0.250 & & & & \\
\hline & smooth & 0.853 & 0.995 & 0.975 & 0.302 & 0.146 & 0.146 & 0.102 & & & & \\
\hline 10 DAYS & wind & 0.923 & 0.065 & 0.038 & 0.698 & 0.146 & 0.146 & 0.250 & & & & \\
\hline & smooth & 0.777 & 0.993 & 0.962 & 0.302 & 0.146 & 0.146 & 0.102 & & & & \\
\hline 20/30 DAYS & wind & 0.813 & 0.065 & 0.038 & 0.698 & 0.146 & 0.146 & 0.250 & & & & \\
\hline & smooth & 0.500 & 0.993 & 0.962 & 0.302 & 0.146 & 0.146 & 0.102 & & & & \\
\hline & & & & & & & ovakia & & & & & \\
\hline 2 DAYS & wind & 0.500 & 0.627 & 0.033 & 0.500 & & & & & & & \\
\hline & smooth & 0.957 & 0.172 & 0.989 & 0.008 & & & & & & & \\
\hline 5 DAYS & wind & 0.807 & 0.923 & 0.013 & 0.500 & & & & & & & \\
\hline & smooth & 0.384 & 0.001 & 0.962 & 0.008 & & & & & & & \\
\hline 10 DAYS & wind & 0.883 & 0.881 & 0.020 & 0.302 & & & & & & & \\
\hline & smooth & 0.271 & 0.002 & 0.942 & 0.032 & & & & & & & \\
\hline 20/30 DAYS & wind & 0.750 & 0.500 & $\underline{0.102}$ & & & & & & & & \\
\hline & smooth & 0.500 & 0.854 & 0.750 & & & & & & & & \\
\hline & & & & Tur & key - & discre & ionary & mit & ention & & & \\
\hline 2 DAYS & wind & & 0.790 & 0.054 & 0.853 & 0.500 & & & & & & \\
\hline & smooth & & 0.906 & 0.998 & 0.050 & 0.146 & & & & & & \\
\hline $5 / 10 / 20 / 30$ DAYS & wind & & 0.713 & 0.080 & 0.777 & 0.500 & & & & & & \\
\hline & smooth & & 0.980 & 0.997 & 0.223 & 0.146 & & & & & & \\
\hline & & & Turke & $y-d i$ & scretio & nary \& & aucti & on-bas & ed int & rententi & ons & \\
\hline 2 DAYS & wind & 0.813 & 0.698 & 0.698 & 0.250 & & & & & & & \\
\hline & smooth & 0.942 & 0.909 & 0.909 & 0.750 & & & & & & & \\
\hline 5/10/20/30 DAYS & wind & 0.500 & 0.250 & 0.250 & 0.250 & & & & & & & \\
\hline & smooth & 0.854 & 0.750 & 0.750 & 0.750 & & & & & & & \\
\hline
\end{tabular}

Notes: see Table B1. Results for Romania are not displayed because success could not be identified for any of the event and pre- and post-event window definitions. 
Table B3. Interest news adjusted for actual and verbal interventions

NONPARAMETRIC SIGN TEST - p-values

\begin{tabular}{|c|c|c|c|c|c|c|c|c|c|c|c|}
\hline \multirow[b]{2}{*}{ EVENT } & \multicolumn{11}{|c|}{ PRE- AND POST-EVENT WINDOW } \\
\hline & & W & 1 & 2 & 5 & 10 & 15 & 20 & 30 & 40 & 60 \\
\hline \multicolumn{12}{|c|}{ Hungary } \\
\hline \multirow[t]{2}{*}{ 2/5 DAYS } & wind & & 0.961 & 0.828 & 0.913 & 0.978 & 0.923 & 0.500 & 0.750 & & \\
\hline & smooth & & 0.992 & 1.000 & 0.992 & 0.978 & 0.969 & 0.942 & 0.045 & & \\
\hline \multirow[t]{2}{*}{10 DAYS } & wind & & 0.975 & 0.780 & 0.942 & 0.962 & 0.946 & 0.500 & 0.750 & & \\
\hline & smooth & & 0.947 & 1.000 & 0.942 & 0.985 & 0.879 & 0.942 & 0.045 & & \\
\hline \multirow[t]{2}{*}{20 DAYS } & wind & 0.500 & 0.750 & 0.834 & 0.500 & 0.902 & 0.642 & 0.500 & 0.750 & & \\
\hline & smooth & 0.146 & 0.938 & 0.999 & 0.991 & 0.902 & 0.983 & 0.942 & 0.045 & & \\
\hline \multirow[t]{2}{*}{30 DAYS } & wind & 0.250 & 0.688 & 0.607 & 0.500 & 0.500 & 0.337 & 0.302 & 0.750 & & \\
\hline & smooth & 0.750 & 0.834 & 0.998 & 0.980 & 0.777 & 0.962 & 0.909 & 0.045 & & \\
\hline \multicolumn{12}{|c|}{ Czech Republic } \\
\hline \multirow[t]{2}{*}{2 DAYS } & wind & & 0.995 & 0.573 & 0.989 & 0.590 & 0.920 & 0.902 & & & \\
\hline & smooth & & 0.989 & 1.000 & 1.000 & 1.000 & 0.807 & 0.098 & & & \\
\hline \multirow[t]{2}{*}{5 DAYS } & wind & & 0.993 & 0.646 & 0.994 & 0.500 & 0.920 & 0.902 & & & \\
\hline & smooth & & 0.984 & 1.000 & 1.000 & 1.000 & 0.807 & 0.098 & & & \\
\hline \multirow[t]{2}{*}{10 DAYS } & wind & & 0.996 & 0.716 & 0.991 & 0.590 & 0.920 & 0.902 & & & \\
\hline & smooth & & 0.978 & 1.000 & 1.000 & 1.000 & 0.807 & 0.098 & & & \\
\hline \multirow[t]{2}{*}{20 DAYS } & wind & 0.500 & 0.993 & 0.500 & 0.983 & 0.500 & 0.807 & 0.627 & & & \\
\hline & smooth & 0.854 & 0.809 & 1.000 & 0.994 & 0.998 & 0.807 & 0.627 & & & \\
\hline \multirow[t]{2}{*}{30 DAYS } & wind & 0.663 & 0.980 & 0.500 & 0.950 & 0.813 & 0.302 & 0.146 & & & \\
\hline & smooth & 0.962 & 0.865 & 0.998 & 0.358 & 0.500 & 0.909 & 0.854 & & & \\
\hline
\end{tabular}

Notes: see Table B1. The remaining countries are not reported because success could not be identified for any of the event and pre- and post-event window definitions.

Table B4. Interest news adjusted for actual and verbal interventions, weakening NONPARAMETRIC SIGN TEST - p-values

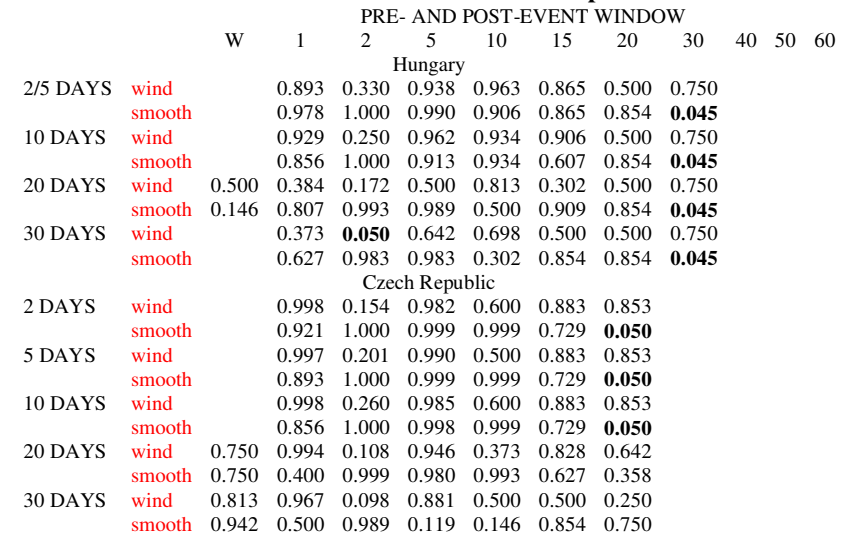

Notes: see Table B3. 
Table B5. Verbal interventions adjusted for actual interventions and interest news, strengthening, Hungary

\section{NONPARAMETRIC SIGN TEST - p-values}

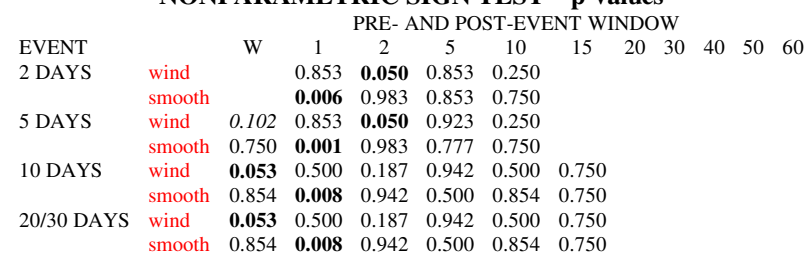

Notes: see Table B3 
Table B6. FX interventions - the combined effect NONPARAMETRIC SIGN TEST - p-values

\begin{tabular}{|c|c|c|c|c|c|c|c|c|c|c|c|c|}
\hline \multirow{2}{*}{ EVENT } & & \multicolumn{11}{|c|}{ PRE- AND POST-EVENT WINDOW } \\
\hline & & $\mathrm{W}$ & 1 & 2 & 5 & 10 & 15 & 20 & 30 & 40 & 50 & 60 \\
\hline & & \multicolumn{11}{|c|}{ Croatia 1996-2001 } \\
\hline \multirow[t]{2}{*}{2 DAYS } & wind & 0.997 & 1.000 & 1.000 & 0.982 & 0.633 & 0.678 & 0.301 & 0.500 & 0.302 & 0.250 & \\
\hline & smooth & 0.993 & 1.000 & 1.000 & 0.030 & 0.048 & 0.087 & 0.301 & 0.500 & 0.302 & 0.750 & \\
\hline \multirow[t]{2}{*}{5 DAYS } & wind & 0.740 & 1.000 & 0.998 & 0.975 & 0.500 & 0.415 & 0.312 & 0.500 & 0.663 & 0.500 & \\
\hline & smooth & 1.000 & 1.000 & 1.000 & 0.025 & 0.065 & 0.260 & 0.166 & 0.777 & 0.119 & 0.146 & \\
\hline \multirow[t]{2}{*}{10 DAYS } & wind & 0.961 & 1.000 & 0.944 & 0.301 & 0.382 & 0.578 & 0.500 & 0.500 & 0.663 & 0.500 & \\
\hline & smooth & 1.000 & 1.000 & 1.000 & 0.217 & 0.117 & 0.578 & 0.500 & 0.500 & 0.119 & 0.146 & \\
\hline \multirow[t]{2}{*}{20 DAYS } & wind & 0.942 & 1.000 & 0.935 & 0.122 & 0.163 & 0.500 & 0.337 & 0.616 & 0.642 & 0.698 & \\
\hline & smooth & 1.000 & 1.000 & 1.000 & 0.878 & 0.578 & 0.789 & 0.663 & 0.807 & 0.358 & 0.302 & \\
\hline \multirow[t]{3}{*}{30 DAYS } & wind & 0.859 & 1.000 & 0.905 & 0.102 & 0.133 & 0.500 & 0.312 & 0.500 & 0.500 & 0.500 & \\
\hline & smooth & 1.000 & 0.998 & 1.000 & 0.820 & 0.938 & 0.985 & 0.969 & 0.934 & 0.500 & 0.500 & \\
\hline & & & & & & Croati & 2001 & -2006 & & & & \\
\hline 2 DAYS & wind & 0.853 & 1.000 & 0.855 & 0.437 & 0.260 & 0.287 & 0.193 & 0.500 & 0.250 & & \\
\hline & smooth & 0.983 & 0.999 & 1.000 & 0.437 & 0.013 & 0.135 & 0.384 & 0.854 & 0.750 & & \\
\hline 5 DAYS & wind & 0.600 & 1.000 & 0.911 & 0.084 & 0.125 & $\underline{0.108}$ & 0.210 & 0.500 & 0.698 & & \\
\hline & smooth & 0.999 & 0.997 & 1.000 & 0.780 & 0.030 & $\overline{0.400}$ & 0.210 & 0.942 & 0.302 & & \\
\hline 10 DAYS & wind & 0.762 & 0.983 & 0.798 & 0.007 & 0.095 & 0.179 & 0.312 & 0.500 & 0.698 & & \\
\hline & smooth & 1.000 & 1.000 & 1.000 & 0.569 & 0.009 & 0.678 & 0.500 & 0.777 & 0.302 & & \\
\hline 20 DAYS & wind & 0.775 & 0.981 & 0.837 & 0.016 & 0.038 & 0.121 & 0.121 & 0.358 & 0.500 & & \\
\hline & smooth & 0.999 & 1.000 & 1.000 & 0.921 & 0.322 & 0.879 & 0.594 & 0.853 & 0.500 & & \\
\hline 30 DAYS & wind & 0.500 & 0.938 & 0.750 & 0.008 & 0.020 & 0.080 & 0.080 & 0.271 & 0.337 & 0.250 & \\
\hline & smooth & 0.999 & 0.999 & 1.000 & 0.879 & 0.865 & 0.997 & 0.971 & 0.957 & 0.663 & $\underline{0.102}$ & \\
\hline & & & & & & Czec & h Rep & ublic & & & & \\
\hline 2 DAYS & wind & 0.956 & 0.500 & 0.125 & 0.775 & 0.080 & 0.373 & 0.223 & 0.337 & 0.500 & 0.750 & 0.750 \\
\hline & smooth & 0.993 & 0.997 & 1.000 & 0.108 & 0.384 & 0.627 & 0.223 & 0.013 & 0.008 & 0.045 & 0.045 \\
\hline 5 DAYS & wind & 0.834 & 0.415 & 0.062 & 0.500 & 0.301 & 0.616 & 0.147 & 0.337 & 0.500 & 0.750 & 0.750 \\
\hline & smooth & 0.996 & 0.999 & 1.000 & 0.500 & 0.009 & 0.080 & 0.358 & 0.013 & 0.008 & 0.045 & 0.045 \\
\hline 10 DAYS & wind & 0.775 & 0.330 & 0.038 & 0.600 & 0.301 & 0.616 & 0.147 & 0.337 & 0.500 & 0.750 & 0.750 \\
\hline & smooth & 0.994 & 0.999 & 1.000 & 0.400 & 0.009 & 0.080 & 0.358 & 0.013 & 0.008 & 0.045 & 0.045 \\
\hline 20/30 DAYS & wind & 0.790 & 0.238 & 0.045 & 0.500 & 0.384 & 0.500 & 0.172 & 0.358 & 0.337 & 0.500 & 0.500 \\
\hline & smooth & 0.987 & 0.997 & 0.999 & 0.500 & 0.010 & 0.271 & 0.172 & 0.006 & 0.013 & 0.026 & 0.026 \\
\hline & & & & & & & Jungar & & & & & \\
\hline Single event & & & & $\mathrm{W}$ & W & W & $\mathrm{W}$ & W & $\mathrm{W}$ & W & $\mathrm{W}$ & $\mathrm{W}$ \\
\hline & & & & & & & oman & & & & & \\
\hline 2/5 DAYS & wind & 0.698 & 0.923 & 0.337 & 0.962 & 0.909 & 0.750 & & & & & \\
\hline & smooth & 0.909 & 0.777 & 0.962 & 0.663 & 0.909 & 0.750 & & & & & \\
\hline 10 DAYS & wind & 0.698 & 0.881 & 0.500 & 0.813 & 0.813 & 0.500 & & & & & \\
\hline & smooth & 0.909 & 0.663 & 0.942 & 0.942 & 0.942 & 0.854 & & & & & \\
\hline 20/30 DAYS & wind & 0.250 & 0.500 & 0.250 & 0.250 & 0.250 & 0.250 & & & & & \\
\hline & smooth & 0.750 & 0.146 & 0.750 & 0.750 & 0.750 & 0.750 & & & & & \\
\hline & & & & & & & lovaki & & & & & \\
\hline 2 DAYS & wind & 0.848 & 0.582 & 0.731 & 0.688 & 0.022 & 0.058 & 0.058 & 0.032 & 0.302 & & \\
\hline & smooth & 0.991 & 0.984 & 1.000 & 0.500 & 0.993 & 0.500 & 0.942 & 0.909 & 0.302 & & \\
\hline 5 DAYS & wind & 0.934 & 0.762 & 0.594 & 0.594 & 0.080 & 0.119 & 0.119 & 0.020 & 0.187 & 0.250 & 0.102 \\
\hline & smooth & 0.934 & 0.238 & 1.000 & 0.594 & 0.807 & 0.119 & 0.663 & 0.942 & 0.500 & 0.750 & 0.750 \\
\hline 10 DAYS & wind & 0.963 & 0.600 & 0.600 & 0.400 & 0.094 & 0.077 & 0.077 & 0.013 & 0.119 & 0.146 & 0.053 \\
\hline & smooth & 0.906 & 0.400 & 0.999 & 0.775 & 0.906 & 0.223 & 0.777 & 0.962 & 0.663 & 0.854 & 0.854 \\
\hline 20/30 DAYS & wind & 0.957 & 0.384 & 0.616 & 0.193 & 0.007 & 0.065 & 0.022 & 0.017 & 0.147 & 0.187 & 0.187 \\
\hline & smooth & 0.995 & 0.971 & 0.997 & 0.080 & 0.935 & 0.172 & 0.935 & 0.853 & 0.358 & 0.500 & 0.058 \\
\hline & & & & & Irkey - & discr & etionar & ry inter & ventic & & & \\
\hline 2 DAYS & wind & & 0.762 & 0.238 & 0.879 & 0.600 & 0.729 & 0.500 & 0.119 & 0.032 & 0.091 & \\
\hline & smooth & & 0.978 & 1.000 & 0.008 & 0.400 & 0.271 & 0.729 & 0.663 & 0.909 & 0.302 & \\
\hline 5 DAYS & wind & & 0.688 & 0.312 & 0.834 & 0.688 & 0.729 & 0.500 & 0.119 & 0.032 & 0.091 & \\
\hline & smooth & & 0.996 & 0.999 & 0.031 & 0.166 & 0.271 & 0.729 & 0.663 & 0.909 & 0.302 & \\
\hline 10 DAYS & wind & 0.250 & 0.600 & 0.400 & 0.775 & 0.775 & 0.616 & 0.384 & 0.077 & 0.032 & 0.091 & \\
\hline & smooth & 0.750 & 0.994 & 0.999 & 0.017 & 0.108 & 0.384 & 0.807 & 0.777 & 0.909 & 0.302 & \\
\hline 20 DAYS & wind & 0.250 & 0.699 & 0.301 & 0.500 & 0.699 & 0.713 & 0.500 & 0.077 & 0.032 & 0.091 & \\
\hline & smooth & 0.750 & 0.991 & 0.999 & 0.066 & 0.301 & 0.135 & 0.500 & 0.777 & 0.909 & 0.302 & \\
\hline 30 DAYS & wind & 0.500 & 0.713 & 0.287 & 0.500 & 0.713 & 0.500 & 0.271 & 0.033 & 0.020 & 0.058 & 0.102 \\
\hline & smooth & 0.854 & 0.865 & 0.998 & 0.135 & 0.500 & 0.271 & 0.729 & 0.902 & 0.942 & 0.500 & 0.750 \\
\hline & & & Turk & rey $-\mathrm{d}$ & iscreti & onary & $\&$ auc & tion-ba & ssed in & terven & tions & \\
\hline 2 DAYS & wind & 0.172 & 0.301 & 0.934 & 0.172 & 0.013 & 0.250 & 0.250 & 0.250 & 0.250 & 0.250 & \\
\hline & smooth & 0.993 & 0.934 & 0.999 & 0.172 & 0.962 & 0.102 & 0.102 & $\underline{0.102}$ & $\underline{0.102}$ & 0.750 & \\
\hline 5 DAYS & wind & 0.119 & 0.373 & 0.627 & 0.172 & 0.013 & 0.250 & 0.250 & 0.250 & 0.250 & 0.250 & \\
\hline & smooth & 0.962 & 0.935 & 0.993 & 0.627 & 0.962 & $\underline{0.102}$ & $\underline{0.102}$ & $\underline{0.102}$ & $\underline{0.102}$ & 0.750 & \\
\hline 10/20/30 DAYS & wind & 0.187 & 0.250 & 0.500 & 0.098 & 0.025 & 0.146 & 0.250 & 0.250 & 0.250 & 0.250 & \\
\hline & smooth & 0.942 & 0.500 & 0.989 & 0.500 & 0.975 & 0.146 & $\underline{0.102}$ & $\underline{0.102}$ & $\underline{0.102}$ & 0.750 & \\
\hline
\end{tabular}

Notes: see Table B1. 
Table B7. FX interventions - the combined effect: direction matters; weakening NONPARAMETRIC SIGN TEST - p-values

\begin{tabular}{|c|c|c|c|c|c|c|c|c|c|c|c|c|}
\hline \multirow{2}{*}{ EVENT } & \multicolumn{12}{|c|}{ DUW } \\
\hline & & $\mathrm{W}$ & 1 & 2 & 5 & 10 & 15 & 20 & 30 & 40 & 50 & 60 \\
\hline & & \multicolumn{11}{|c|}{ Croatia - 1996-2005 } \\
\hline \multirow[t]{2}{*}{2 DAYS } & wind & 0.990 & 1.000 & 0.017 & 0.888 & 0.337 & 0.384 & 0.271 & 0.500 & 0.250 & & \\
\hline & smooth & 0.971 & 1.000 & 1.000 & 0.935 & 0.663 & 0.384 & 0.729 & 0.854 & 0.750 & & \\
\hline \multirow{2}{*}{5 DAYS } & wind & 0.590 & 1.000 & 0.048 & 0.721 & 0.133 & 0.152 & 0.287 & 0.500 & 0.698 & 0.250 & \\
\hline & smooth & 0.999 & 1.000 & 1.000 & 0.615 & 0.772 & 0.699 & 0.500 & 0.942 & 0.302 & 0.102 & \\
\hline \multirow[t]{2}{*}{10 DAYS } & wind & 0.856 & 0.999 & 0.033 & 0.312 & 0.141 & 0.322 & 0.500 & 0.500 & 0.698 & 0.250 & \\
\hline & smooth & 0.999 & 1.000 & 1.000 & 0.312 & 0.641 & 0.913 & 0.834 & 0.777 & 0.302 & 0.102 & \\
\hline \multirow[t]{2}{*}{20 DAYS } & wind & 0.821 & 1.000 & 0.172 & 0.116 & 0.133 & 0.500 & 0.406 & 0.750 & 0.813 & 0.500 & \\
\hline & smooth & 0.998 & 0.994 & 1.000 & 0.989 & 0.750 & 0.913 & 0.879 & 0.902 & 0.500 & 0.146 & \\
\hline \multirow[t]{3}{*}{30 DAYS } & wind & 0.688 & 0.998 & 0.107 & 0.133 & 0.152 & 0.607 & 0.500 & 0.729 & 0.663 & 0.302 & \\
\hline & smooth & 0.996 & 0.970 & 1.000 & 0.938 & 0.934 & 0.987 & 0.980 & 0.957 & 0.663 & 0.302 & \\
\hline & & \multicolumn{11}{|c|}{ Croatia $-2001-2006$} \\
\hline \multirow[t]{2}{*}{2 DAYS } & wind & 0.881 & 1.000 & 0.079 & 0.578 & 0.152 & 0.250 & 0.250 & 0.750 & & & \\
\hline & smooth & 0.962 & 0.998 & 1.000 & 0.958 & 0.301 & 0.500 & 0.500 & 0.750 & & & \\
\hline \multirow[t]{2}{*}{5 DAYS } & wind & 0.616 & 0.999 & 0.180 & 0.133 & 0.062 & 0.080 & 0.271 & 0.698 & 0.854 & & \\
\hline & smooth & 0.997 & 0.989 & 1.000 & 0.984 & 0.410 & 0.807 & 0.271 & 0.909 & 0.146 & & \\
\hline \multirow[t]{2}{*}{10 DAYS } & wind & 0.865 & 0.984 & 0.079 & 0.022 & 0.062 & 0.152 & 0.393 & 0.663 & 0.854 & & \\
\hline & smooth & 0.998 & 0.998 & 1.000 & 0.663 & 0.133 & 0.934 & 0.607 & 0.663 & 0.146 & & \\
\hline \multirow[t]{2}{*}{20 DAYS } & wind & 0.500 & 0.978 & 0.238 & 0.031 & 0.066 & 0.210 & 0.210 & 0.663 & 0.854 & & \\
\hline & smooth & 0.995 & 0.997 & 1.000 & 0.969 & 0.301 & 0.906 & 0.607 & 0.663 & 0.146 & & \\
\hline 30 DAYS & wind & 0.250 & 0.865 & 0.135 & 0.029 & 0.065 & 0.250 & 0.250 & 0.642 & 0.698 & 0.250 & \\
\hline & smooth & 0.989 & 0.980 & 0.998 & 0.807 & 0.627 & 0.989 & 0.902 & 0.853 & 0.302 & 0.102 & \\
\hline & & & & & & Czec & h Rep & ublic & & & & \\
\hline 2 DAYS & wind & 0.969 & 0.418 & 0.022 & 0.865 & 0.098 & 0.358 & 0.119 & 0.337 & 0.500 & 0.750 & 0.750 \\
\hline & smooth & 0.969 & 0.984 & 1.000 & 0.020 & 0.098 & 0.358 & 0.119 & 0.013 & 0.008 & 0.045 & 0.045 \\
\hline 5 DAYS & wind & 0.865 & 0.312 & 0.006 & 0.607 & 0.384 & 0.627 & 0.077 & 0.337 & 0.500 & 0.750 & 0.750 \\
\hline & smooth & 0.980 & 0.996 & 0.999 & 0.210 & 0.001 & 0.022 & 0.223 & 0.013 & 0.008 & 0.045 & 0.045 \\
\hline 10 DAYS & wind & 0.807 & 0.225 & 0.003 & 0.713 & 0.384 & 0.627 & 0.077 & 0.337 & 0.500 & 0.750 & 0.750 \\
\hline & smooth & 0.971 & 0.994 & 0.999 & 0.135 & 0.001 & 0.022 & 0.223 & 0.013 & 0.008 & 0.045 & 0.045 \\
\hline 20/30 DAYS & wind & 0.883 & 0.210 & 0.007 & 0.500 & 0.373 & 0.373 & 0.098 & 0.358 & 0.337 & 0.500 & 0.500 \\
\hline & smooth & 0.957 & 0.987 & 0.998 & 0.271 & 0.003 & 0.172 & 0.098 & 0.006 & 0.013 & 0.026 & 0.026 \\
\hline & & & & & & & lovaki & & & & & \\
\hline 2 DAYS & wind & 0.729 & 0.500 & 0.066 & 0.935 & 0.077 & 0.250 & 0.102 & 0.102 & 0.250 & & \\
\hline & smooth & 0.957 & 0.699 & 0.999 & 0.022 & 0.975 & 0.102 & 0.750 & 0.750 & 0.102 & & \\
\hline 5 DAYS & wind & 0.883 & 0.883 & 0.043 & 0.957 & 0.147 & $\overline{0.250}$ & 0.102 & 0.102 & $\overline{0.250}$ & & \\
\hline & smooth & 0.729 & 0.005 & 0.995 & 0.043 & 0.853 & 0.102 & 0.750 & 0.750 & 0.102 & & \\
\hline 10 DAYS & wind & 0.935 & 0.828 & 0.065 & 0.935 & 0.250 & $\overline{0.250}$ & 0.102 & 0.102 & $\overline{0.250}$ & & \\
\hline & smooth & 0.627 & 0.022 & 0.993 & 0.172 & 0.902 & 0.102 & $\overline{0.750}$ & $\overline{0.750}$ & $\underline{0.102}$ & & \\
\hline 20/30 DAYS & wind & 0.923 & 0.663 & 0.038 & 0.881 & 0.020 & 0.187 & 0.020 & 0.091 & $\overline{0.302}$ & 0.250 & 0.750 \\
\hline & smooth & 0.975 & 0.663 & 0.962 & 0.002 & 0.942 & 0.058 & 0.942 & 0.302 & 0.032 & $\underline{0.102}$ & 0.045 \\
\hline & & & & $\mathrm{Tu}$ & Irkey - & - discr & etionar & $y$ inter & rventic & & & \\
\hline 2 DAYS & wind & & 0.848 & 0.066 & 0.848 & 0.713 & 0.750 & 0.750 & 0.302 & $\underline{0.102}$ & 0.102 & \\
\hline & smooth & & 0.934 & 0.999 & 0.066 & 0.135 & 0.500 & 0.500 & 0.302 & 0.750 & 0.750 & \\
\hline 5 DAYS & wind & & 0.790 & 0.094 & 0.790 & 0.790 & 0.750 & 0.750 & 0.302 & $\underline{0.102}$ & 0.102 & \\
\hline & smooth & & 0.987 & 0.998 & 0.210 & 0.037 & 0.500 & 0.500 & 0.302 & $\overline{0.750}$ & $\overline{0.750}$ & \\
\hline 10 DAYS & wind & 0.250 & 0.713 & 0.135 & 0.713 & 0.865 & 0.627 & 0.627 & 0.187 & 0.102 & 0.102 & \\
\hline & smooth & 0.750 & 0.980 & 0.998 & 0.135 & 0.020 & 0.627 & 0.627 & 0.500 & 0.750 & 0.750 & \\
\hline 20 DAYS & wind & 0.250 & 0.807 & 0.080 & 0.384 & 0.807 & 0.729 & 0.729 & 0.187 & 0.102 & 0.102 & \\
\hline & smooth & 0.750 & 0.971 & 0.997 & 0.384 & 0.080 & 0.271 & 0.271 & 0.500 & 0.750 & 0.750 & \\
\hline 30 DAYS & wind & 0.500 & 0.828 & 0.065 & 0.373 & 0.828 & 0.500 & 0.500 & 0.077 & 0.053 & 0.053 & \\
\hline & smooth & 0.854 & 0.627 & 0.993 & 0.627 & 0.172 & 0.500 & 0.500 & 0.777 & 0.854 & 0.854 & \\
\hline & & & Turk & ey $-d$ & iscreti & onary & $\&$ auc & ion-ba & ased in & terven & tions & \\
\hline 2 DAYS & wind & 0.663 & 0.500 & 0.223 & 0.058 & 0.032 & 0.250 & 0.250 & 0.250 & 0.250 & 0.250 & \\
\hline & smooth & 0.962 & 0.777 & 0.975 & 0.942 & 0.909 & 0.102 & 0.102 & 0.102 & 0.102 & 0.750 & \\
\hline 5 DAYS & wind & 0.302 & 0.187 & 0.058 & 0.058 & 0.032 & $\overline{0.250}$ & $\overline{0.250}$ & $\overline{0.250}$ & $\overline{0.250}$ & 0.250 & \\
\hline & smooth & 0.909 & 0.500 & 0.942 & 0.942 & 0.909 & 0.102 & 0.102 & 0.102 & 0.102 & 0.750 & \\
\hline 10/20/30 DAYS & wind & 0.302 & 0.187 & 0.058 & 0.058 & 0.032 & $\overline{0.250}$ & $\overline{0.250}$ & $\overline{0.250}$ & $\overline{0.250}$ & 0.250 & \\
\hline & smooth & 0.909 & 0.500 & 0.942 & 0.942 & 0.909 & $\underline{0.102}$ & $\underline{0.102}$ & $\underline{0.102}$ & $\underline{0.102}$ & 0.750 & \\
\hline
\end{tabular}

Notes: see Table B1. Results for Romania are not reported because success could not be identified for any of the event and pre- and post-event window definitions. 
Table B8. FX interventions - the combined effect: direction matters; strengthening NONPARAMETRIC SIGN TEST - p-values

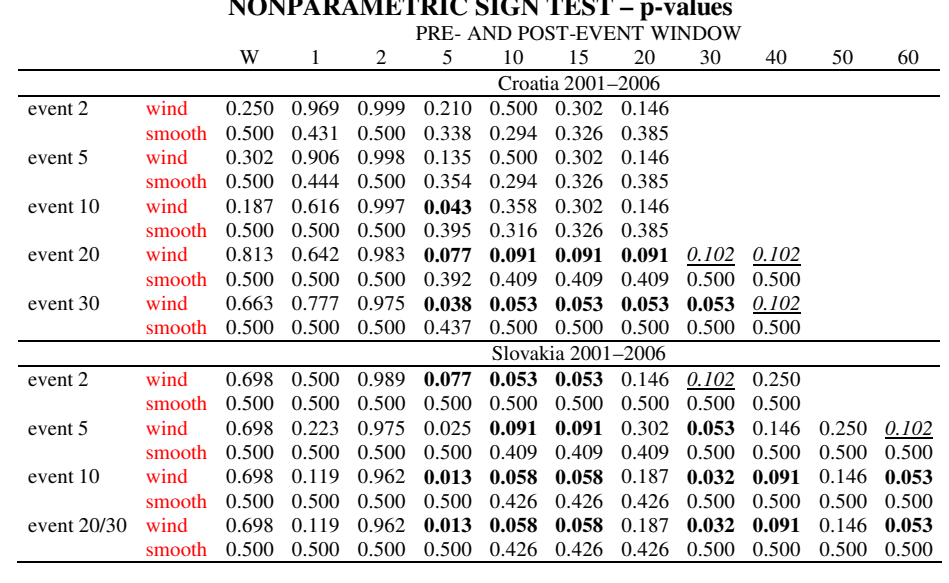

Notes: see Table B1. Results for the remaining countries are not reported because success could not be identified for any of the event and pre- and post-event window definitions. 


\section{Discussion Papers published since 1999}

\section{4}

Gergely CSORBA: Screening Contracts in the Presence of Positive Net-work Effects MT-DP. 2004/14

K. BOGNÁR - L. SMITH: We Can’t Argue Forever MT-DP. 2004/15

JUHÁSZ A. - SERES A. - STAUDER M.: A kereskedelmi koncentráció módszertana MTDP. 2004/16

Júlia LENDVAI: Inflation Inertia and Monetary Policy Shocks MT-DP. 2004/17

A. FREDERIKSEN -E. TAKÁTS: Optimal Incentive Mix of Performance Pay and Efficiency Wage MT-DP. 2004/18

Péter KONDOR: The More We Know, the Less We Agree: Public Announcements and Higher-Order Expectations. MT-DP. 2004/19

BARANYI B. -BALCSÓK I.: Határmenti együttmúködés és a foglalkoztatás - keletmagyarországi helyzetkép. MT-DP. 2004/20

L.Á. KÓCZY - L. LAUWERS: The Minimal Dominant Set is a Non-Empty Core-Extension. MT-DP. 2004/21

Miklós KOREN: The Law of Two Prices: Trade Costs and Relative Price Variability MT-DP. 2004/22

A. AMBRUS - R. ARGENZIANO: Network Markets and Consumer Coordination. MT-DP. 2004/23

LÓCSEI Hajnalka: A vidéki városi agglomerációk fejlődési pályája. MT-DP. 2004/24

J.D.BROWN - J.S. EARLE - Á. TELEGDY: Does Privatization Raise Productivity?. MT-DP. 2004/25

HÁRS Ágnes: A magyar munkaerő-migráció regionális sajátosságairól MT-DP. 2004/26

2005

GÁCS János: A lisszaboni folyamat: rejtélyek, elméleti problémák és gyakorlati nehézségek. MT-DP. 2005/1

PÉTERI Gábor: Igazodás a piacgazdaság szabályaihoz és megfelelés a helyi elvárásoknak - A városi polgármesterek értékrendje, 2004. MT-DP. 2005/2

SZALAI Ákos: Adóverseny az iparűzési adóban - Az 5000 fő fölötti települések adópolitikája a 2000-es években. MT-DP. 2005/3

Gábor BÉKÉS - Balázs MURAKÖZY: Firm Behaviour and Public Infrastructure: The Case of Hungary. MT-DP. 2005/4

Gusztav NEMES: The Politics of Rural Development in Europe. MT-DP. 2005/5

Gusztav NEMES: Integrated Rural Development - the Concept and Its Operation. MT-DP. 2005/6

JUHÁSZ Anikó -SERES Antal -STAUDER Márta: A kereskedelmi koncentráció tendenciái MT-DP. 2005/7

Hajnalka TARJÁNI: Estimating some Labour Market Implications of Skill Biased Technology Change and imports in Hungary. MT-DP. 2005/8

L. HALPERN - M.KOREN.- Á. SZEIDL: Import and Productivity. MT-DP. 2005/9

Szabolcs LŐRINCZ: Persistence Effects in a Dynamic Discrete Choice Model - Application to Low-End Computer Servers. MT-DP. 2005/10

Péter VIDA: A Detail-free Mediator and the 3 Player Case. MT-DP. 2005/11

László Á. KÓCZY: The Core Can Be Accessed with a Bounded Number of Blocks. MT-DP. 2005/12 
Viktória KOCSIS: Network Asymmetries and Access Pricing in Cellular Telecommunications. MT-DP. 2005/13

István KÓNYA: Economic Development, Exchange Rates, and the Structure of Trade. MTDP. 2005/14

Gábor G. SZABÓ - Krisztina BÁRDOS: Vertical Coordination by Contracts in Agribusiness: An Empirical Research in the Hungarian Dairy Sector MT-DP. 2005/15

Attila AMBRUS: Theories of Coalitional Rationality. MT-DP. 2005/16

Jin-Chuan DUAN - András FÜLÖP: Estimating the Structural Credit Risk Model When

Equity Prices Are Contaminated by Trading Noises. MT-DP. 2005/17

Lawrence UREN - Gábor VIRÁG: Wage Inequality in a Burdett-Mortensen World. MT-DP. 2005/18

Berthold HERRENDORF - Ákos VALENTINYI: Which Sectors Make the Poor Countries so Unproductive? MT-DP. 2005/19

János GÁCS: The Macroeconomic Conditions of EU-inspired Employment Policies. MT-DP. 2005/20

CSATÓ Katalin: Egy fiziokrata: Paul-Pierre Le Mercier de la Rivière. MT-DP. 2005/21

\section{6}

Krisztina MOLNÁR - Sergio SANTORO: Optimal Monetary Policy When Agents Are Learning. MT-DP. 2006/1

András SIMONOVITS: Social Security Reform in the US: Lessons from Hungary. MT-DP. 2006/2

Iván MAJOR - Why do (or do not) banks share customer information?. A comparison of mature private credit markets and markets in transition. MT-DP. 2006/3

Mária LACKÓ: Tax Rates with Corruption: Labour-market Effects. Empirical Cross-country Comparisons on OECD Countries. MT-DP. 2006/4

György MOLNÁR - Zsuzsa KAPITÁNY: Mobility, Uncertainty and Subjective Well-being in Hungary. MT-DP. 2006/5

Rozália PÁL - Roman KOZHAN: Firms' investment under financing constraints. A euro area investigation. MT-DP. 2006/6

Anna IARA: Skill diffusion by temporary migration? Returns to Western European working experience in the EU accession countries. MT-DP. 2006/7

György MOLNÁR - Zsuzsa KAPITÁNY: Uncertainty and the Demand for Redistribution. MT-DP. 2006/8

Péter BENCZÚR - István KÓNYA: Nominal growth of a small open economy. MT-DP. 2006/9

Gábor VIRÁG: Outside offers and bidding costs. MT-DP. 2006/10

Péter CSÓKA - P. Jean-Jacques HERINGS - László Á. KÓCZY: Coherent Measures of Risk from a General Equilibrium Perspective. MT-DP. 2006/11

Norbert MAIER: Common Agency with Moral Hazard and Asymmetrically Informed Principals. MT-DP.2006/12

CSERES-GERGELY Zsombor - CSORBA Gergely: Múkincs vagy müködő tőke? Gondolatok a kutatási célú adatok hozzáférhetőségérôl. MT-DP.2006/13

Dr. SERES Antal: Koncentráció a hazai kereskedelemben. MT-DP.2006/14

Discussion Papers are available at the website of Institute of Economics Hungarian Academy of Sciences: http://econ.core.hu 